\title{
Analysis of hot spots in boilers of organic Rankine cycle units during transient operation
}

Benato, A.; Kærn, Martin Ryhl; Pierobon, Leonardo; Stoppato, A.; Haglind, Fredrik

Published in:

Applied Energy

Link to article, DOI:

10.1016/j.apenergy.2015.04.055

Publication date:

2015

Document Version

Peer reviewed version

Link back to DTU Orbit

Citation (APA):

Benato, A., Kærn, M. R., Pierobon, L., Stoppato, A., \& Haglind, F. (2015). Analysis of hot spots in boilers of organic Rankine cycle units during transient operation. Applied Energy, 151, 119-131.

https://doi.org/10.1016/j.apenergy.2015.04.055

\section{General rights}

Copyright and moral rights for the publications made accessible in the public portal are retained by the authors and/or other copyright owners and it is a condition of accessing publications that users recognise and abide by the legal requirements associated with these rights.

- Users may download and print one copy of any publication from the public portal for the purpose of private study or research.

- You may not further distribute the material or use it for any profit-making activity or commercial gain

- You may freely distribute the URL identifying the publication in the public portal 


\title{
Analysis of hot spots in boilers of organic Rankine cycle units during transient operation
}

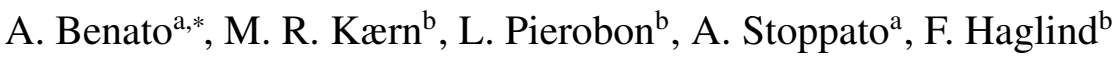 \\ ${ }^{a}$ Department of Industrial Engineering, University of Padova \\ Building Ex-DIM, via Venezia 1, 35131 Padova, Italy \\ ${ }^{b}$ Department of Mechanical Engineering, Technical University of Denmark \\ Building 403, 2800 Kongens Lyngby, Denmark
}

\begin{abstract}
This paper is devoted to the investigation of critical dynamic events causing thermochemical decomposition of the working fluid in organic Rankine cycle power systems. The case study is the plant of an oil and gas platform where one of the three gas turbines is combined with an organic Rankine cycle unit to increase the overall energy conversion efficiency.

The dynamic model of the plant is coupled with a one-dimensional model of the once-through boiler fed by the exhaust thermal power of the gas turbine. The heat exchanger model uses a distributed cross-flow physical topology and local correlations for single- and two-phase heat transfer coefficients.
\end{abstract}

The results indicate that severe load changes $\left(0.4-1.0 \mathrm{MW} \cdot \mathrm{s}^{-1}\right)$ can lead to exceedance of the temperature limit of fluid decomposition for a period of $10 \mathrm{~min}$. Ramp rates lower than $0.3 \mathrm{MW} \cdot \mathrm{s}^{-1}$ are acceptable considering the stability of the electric grid and fluid decomposition. It is demonstrated that the use of a spray attemperator can mitigate the problems of local overheating of the organic compound.

As a practical consequence, this paper provides guidelines for safe and reliable operation of organic Rankine cycle power modules on offshore installations.

Keywords: Hot spot, Organic Rankine cycles, Fluid thermochemical decomposition, Waste heat recovery unit.

${ }^{*}$ Corresponding author: Tel: +39 049827 6752; fax: +39 0498276785

Email address: alberto. benato@unipd.it (A. Benato) 


\begin{tabular}{|c|c|c|c|}
\hline \multicolumn{4}{|c|}{ Nomenclature } \\
\hline$A$ & area $\left[\mathrm{m}^{2}\right]$ & $H P C$ & high pressure compressor \\
\hline$C_{o}$ & dimensionless parameter eq. A.3 & $H P T$ & high pressure turbine \\
\hline$D$ & outer tube diameter $[\mathrm{m}]$ & $H R S G$ & heat recovery steam generator \\
\hline$G$ & mass flux $\left[\mathrm{kg} \cdot \mathrm{m}^{-2} \cdot \mathrm{s}^{-1}\right]$ & $L P C$ & low pressure compressor \\
\hline$N$ & dimensionless parameter eq. A.3 & $L P T$ & low pressure turbine \\
\hline$T$ & temperature $[\mathrm{K}]$ & ORC & organic Rankine cycle \\
\hline$x$ & operand eq. A.22 $\left[\mathrm{m}^{-1}\right]$ & OTB & once-through boiler \\
\hline$\dot{m}$ & mass flow rate $\left[\mathrm{kg} \cdot \mathrm{s}^{-1}\right]$ & $P T$ & power turbine \\
\hline Bo & boiling number & $T U R$ & organic Rankine cycle expander \\
\hline $\mathrm{Fr}$ & Froude number & \multicolumn{2}{|l|}{ Greek letters } \\
\hline $\mathrm{Nu}$ & Nusselt number & $\delta$ & fin thickness $[\mathrm{m}]$ \\
\hline $\operatorname{Pr}$ & Prandtl number & $\eta$ & fin efficiency \\
\hline $\operatorname{Re}$ & Reynolds number & $\mu$ & viscosity $\left[\mathrm{kg} \cdot \mathrm{m}^{-1} \cdot \mathrm{s}^{-1}\right]$ \\
\hline$c$ & speed of sound $\left[\mathrm{m} \cdot \mathrm{s}^{-1}\right]$ & $\rho$ & density $\left[\mathrm{kg} \cdot \mathrm{m}^{-3}\right]$ \\
\hline$c_{p}$ & specific heat capacity $\left[\mathrm{J} \cdot \mathrm{kg}^{-1} \cdot \mathrm{K}^{-1}\right]$ & $\varphi$ & operand eq. A.22 \\
\hline$d$ & inner tube diameter $[\mathrm{m}]$ & \multicolumn{2}{|l|}{ Subscripts } \\
\hline$f_{D}$ & Darcy friction factor & $c$ & cold fluid \\
\hline$g$ & gravity acceleration $\left[\mathrm{m} \cdot \mathrm{s}^{-2}\right]$ & $f$ & fin \\
\hline$h$ & heat transfer coefficient $\left[\mathrm{W} \cdot \mathrm{m}^{-2} \cdot \mathrm{K}^{-1}\right]$ or en- & $G$ & gas \\
\hline & thalpy $\left[\mathrm{J} \cdot \mathrm{kg}^{-1}\right]$ & $h$ & hot fluid \\
\hline$h_{\mathrm{LG}}$ & heat of evaporation $\left[\mathrm{J} \cdot \mathrm{kg}^{-1}\right]$ & in & inlet \\
\hline$k$ & thermal conductivity $\left[\mathrm{W} \cdot \mathrm{m}^{-1} \cdot \mathrm{K}^{-1}\right]$ & $L$ & liquid \\
\hline$p$ & pressure $[\mathrm{Pa}]$ & $o$ & overall \\
\hline$q$ & heat flow rate [W] & $S$ & static \\
\hline$q^{\prime \prime}$ & heat flux $\left[\mathrm{W} \cdot \mathrm{m}^{-2}\right]$ & $T$ & total \\
\hline$s$ & entropy $\left[\mathrm{J} \cdot \mathrm{kg}^{-1} \cdot \mathrm{K}^{-1}\right]$ & $t 0$ & bare tube surface \\
\hline$x$ & vapour quality & th & throat \\
\hline Abbreviations & & $w i$ & inner wall \\
\hline$C C$ & combustion chamber & wo & outer wall \\
\hline GEN & electric generator & $c b$ & convective boiling \\
\hline$G T A, G T B, G T C$ & gas turbine $\mathrm{A}, \mathrm{B}$ and $\mathrm{C}$ & $n b$ & nucleate boiling \\
\hline
\end{tabular}




\section{Introduction}

Although investigated since the 1880s, Organic Rankine Cycles (ORC) have never been popular until today's growing interest in medium and low grade energy recovery systems where cycles using water as working fluid fail for technical and economic reasons [1,2].

Organic fluids, i.e., refrigerants and hydrocarbons [3], can mitigate the technical problems associated with the use of steam. These compounds feature higher molecular mass and lower critical temperature than water. These aspects can make small or medium scale power plants technologically and economically feasible.

Their cycle architecture is similar to that of conventional steam Rankine cycles. The high pressure liquid is first evaporated, then expanded to a lower pressure, thus producing mechanical power. The cycle is closed by condensing the low pressure vapour (coming from the turbine outlet) and pumping the liquid to the high pressure side. Hence, an ORC unit has the same devices as a conventional steam power module: an evaporator, an expander, a condenser and a pump.

An organic Rankine cycle has several advantages over steam power plants, as pointed out by Tchanche et al. [3]. The evaporation process, usually taking place at lower temperature and pressure, requires less heat. Superheating is not required, and the risk of turbine blades erosion is avoided as the expansion process ends in the vapour region. Moreover, the relatively low pressure ratio of the expander enables the use of simple single stage turbines.

The ORC technology is suitable for recovering heat from solar radiation [4-12], ocean warm layers [13-17], hydro-thermal and engineered geothermal systems [18-21], abandoned oil fields [22-24], biomass [25-29], and industrial processes [1, 30, 31].

The choice of the working fluid tightly relates to the characteristics of the heat reservoir, as it determines the configuration, performance and economics of the plant [32]. These aspects justify the abundant literature dedicated to the fluid selection (see for example [33, 34]) and plant configurations [35].

As pointed out by Pasetti et al. [36], another key parameter is the thermal stability of the organic fluid. It is defined as the maximum temperature at which the fluid can be used in power plants without risk of decomposition. Fluid overheating or hot spot and the consequent fluid 
decomposition is more likely to occur in the vapour film in contact with the tube metal walls of the terminal part of the primary heat exchanger. As the system performance strongly relates to transport and physical properties of the working fluid, hot spots can severely reduce the net power output, the fluid stability and the components' integrity [37].

Fluid thermochemical decomposition depends on the breakage of chemical bonds between the molecules and the formation of smaller compounds. These species can then react to create other hydrocarbons. Although studies on the thermal stability of organic compounds date back to the early 60's [36], the data available in literature are scarce and often contradictory [2, 37-39]. These research efforts paid attention to the development of testing techniques to quantify the maximum operating temperatures of the organic fluid.

The hot spot phenomenon is in some way analogous to that observed in the materials of boiler tubes, core of nuclear reactors and heat exchangers. Tanzer [40] described the effect of long-term material overheating on the lifetime of steam boilers. The overheating of the tube metal wall induces a reaction between the steam and the tube material itself. The result is an adhesive oxide layer. This additional resistance induces the deterioration of the metal walls as the temperature raises to the maximum tolerable limit. As surveyed by French [41], hot spot corrosion on the steam side of operating boiler tubes of fossil fuel-fired power plants is imputable to the departure from nucleate boiling. This phenomenon leads to acid or caustic attack, and deteriorates the protective magnetite film of the tube walls.

Occurrence of hot spots is a well-known problem in the core of nuclear reactors. This chemical process occurs if the ratio between the power density insisting on the fuel and its average value at design conditions exceeds the prescribed threshold. Statistical analysis and probabilistic evaluations were performed by Amendola [42] and Zhang et al. [43], respectively. Measurement techniques for hot spot identification in nuclear reactors were proposed by Gandini [44]. As regarding the hot spot formation in heat transfer devices, Francis [45] analysed the conditions inducing corrosion in copper alloys of condenser tubes. Prasher et al. [46] conducted similar investigations for micro heat exchangers utilized in electronic devices.

To the authors' knowledge, the fluid overheating (hot spot) and consequent decomposition during the transient operation of ORC power systems have not been analysed before. As underlined 
1 by Benato et al. [47], dynamic analysis is a powerful tool to evaluate the effects of temperature fluctuations and component overheating during load cycling. The objectives of this paper are: i) 3 to identify the dynamic events causing the thermochemical decomposition of the working fluid of 4 an ORC unit, and ii) to suggest practical measures to tackle this issue.

The case study is the gas turbine-based power plant installed on an offshore oil and gas platform 6 located in the Norwegian Sea. The use of an ORC turbogenerator is proposed to increase the overall energy conversion efficiency (see Pierobon et al. [48, 49]). Reliable operation for this plant is a priority. In fact, the economic revenue of a platform depends on stable production rates over the entire lifetime of the oil and gas field. A dynamic model of the plant based on first principles is developed using the Modelica language. This is then integrated with a discretized model of the once-through boiler (OTB) of the ORC unit. Geometric parameters and state-of-theart correlations for heat transfer in single- and two-phase flow are adopted. This allows to estimate the temperature distribution across the OTB. Different dynamic simulations help identifying the largest possible ramp-rates of the plant. Moreover, a control system to tackle local overheating of the organic compound is proposed.

The case study selected for this paper is presented in Section 2. Subsequently, Section 3 describes the dynamic models, and Section 4 presents their validation. The results are reported and discussed in Section 5. Concluding remarks are given in Section 6.

\section{Case study}

The case study is the gas turbine based-power system installed on the Draugen oil and gas offshore platform. The oil and gas field, located $150 \mathrm{~km}$ from Kristiansund in the Norwegian Sea, was discovered in 1984 and started production in 1993. The facility exports natural gas via the Åsgard gas pipeline to Kårstø (Norway) and oil via a shuttle tanker once every 1-2 weeks. Three Siemens SGT-500 gas turbines cover the electric power demand on board. The normal load is around $19 \mathrm{MW}$, but increases to $25 \mathrm{MW}$ during oil export activities. High reliability and low risk of failure are obtained by sharing the load equally between two turbines. The third one is kept on stand-by. Despite the low energy conversion efficiency, this strategy ensures suitable reserve power 
1 for peak loads and safe operation of the engines. Table 1 reports the design-point specifications of 2 the gas turbines as provided by the manufacturer [50].

Table 1: Design-point specifications for the twin-spool gas turbine installed on the Draugen offshore oil and gas platform.

\begin{tabular}{ll}
\hline Model & Siemens SGT500 \\
\hline Turbine inlet temperature & $850{ }^{\circ} \mathrm{C}$ \\
Exhaust gas temperature $t_{10}$ & $379.2{ }^{\circ} \mathrm{C}$ \\
Exhaust gas mass flow rate $\dot{m}_{10}$ & $91.5 \mathrm{~kg} \cdot \mathrm{s}^{-1}$ \\
Electric power output & $16.5 \mathrm{MW}$ \\
Thermal efficiency & $31.3 \%$ \\
\hline
\end{tabular}

Figure 1 shows the layout of the power system with the organic Rankine cycle unit recuperating the thermal power produced by gas turbine A. The twin-spool engine employs two coaxial shafts coupling the low pressure compressor (LPC) with the low pressure turbine (LPT) and the high pressure compressor (HPC) with the high pressure turbine (HPT). The power turbine (PT) transfers mechanical power through a dedicated shaft to the electric generator (GEN). The fuel entering the the combustion chamber $(\mathrm{CC})$ is natural gas.

Figure 2 illustrates the layout of the once-through boiler fed by the engine exhaust gases. The working fluid enters the first rows of tubes on the exhaust gas outlet end. It is then conducted by U-bends at each row in counter flow with the hot gas until it achieves the desired degree of superheating. A header collects the generated vapour which then proceeds to the turbine inlet.

The working fluid is preheated and evaporated continuously within each of the parallel circuits. Gravity is not used to create the head. A centrifugal pump produces forced flow in the tubes. In OTBs a thin-walled separator, not shown in Figure 2, replaces the function of the high-pressure drum of conventional heat recovery steam generators. Such component performs the function of water/steam separation during start-up and shut-down. At steady state operations, including low loads, the steam at the evaporator outlet is slightly superheated. Consequently, no separation is needed. The steam flow thus passes through this component as part of the interconnecting piping toward the superheater [51]. The superheated fluid expands in a single-stage axial turbine me- 


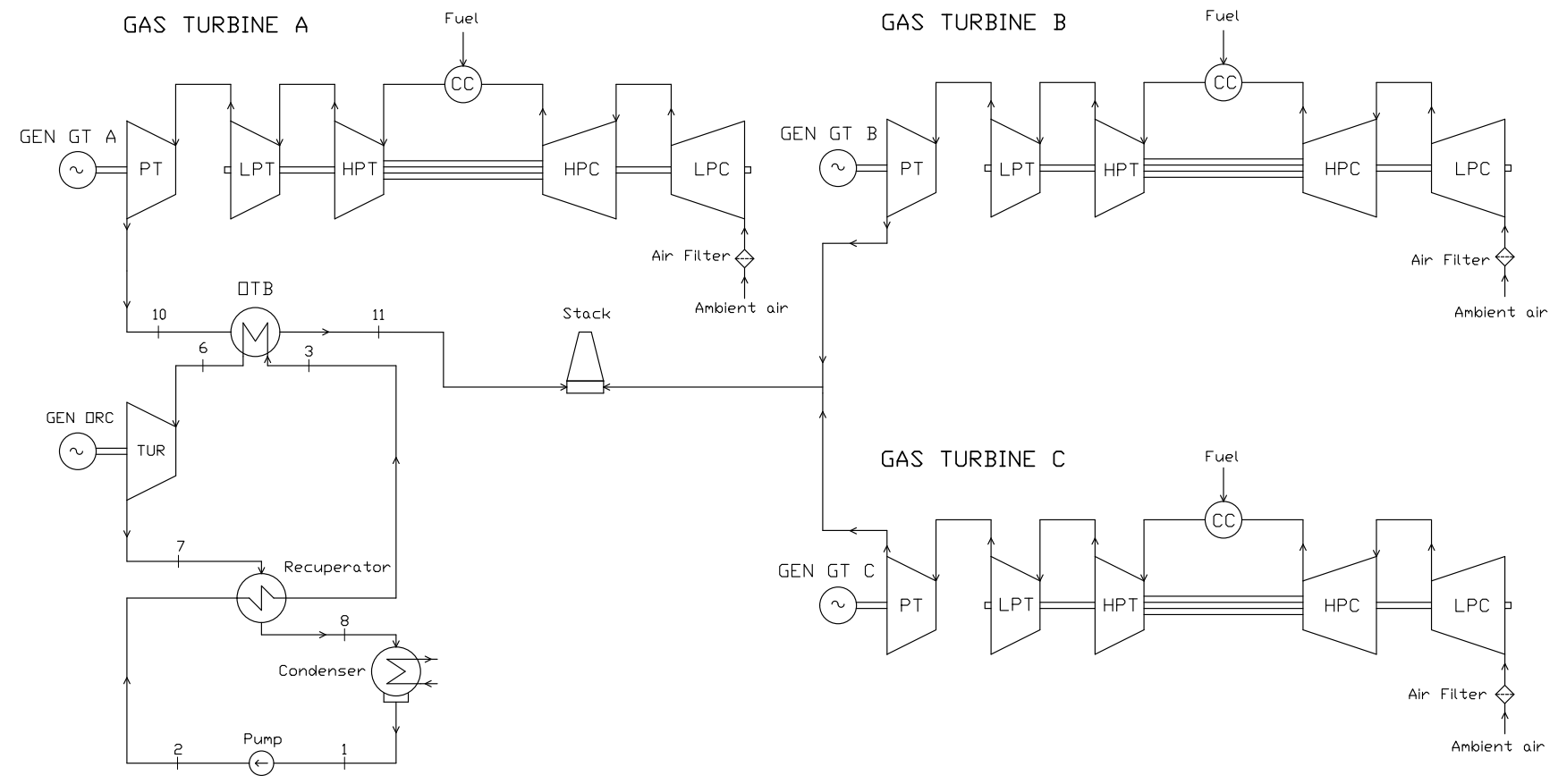

Figure 1: Layout of the power system on the Draugen oil and gas platform. The organic Rankine cycle unit recovers the thermal power of one engine (gas turbine A).

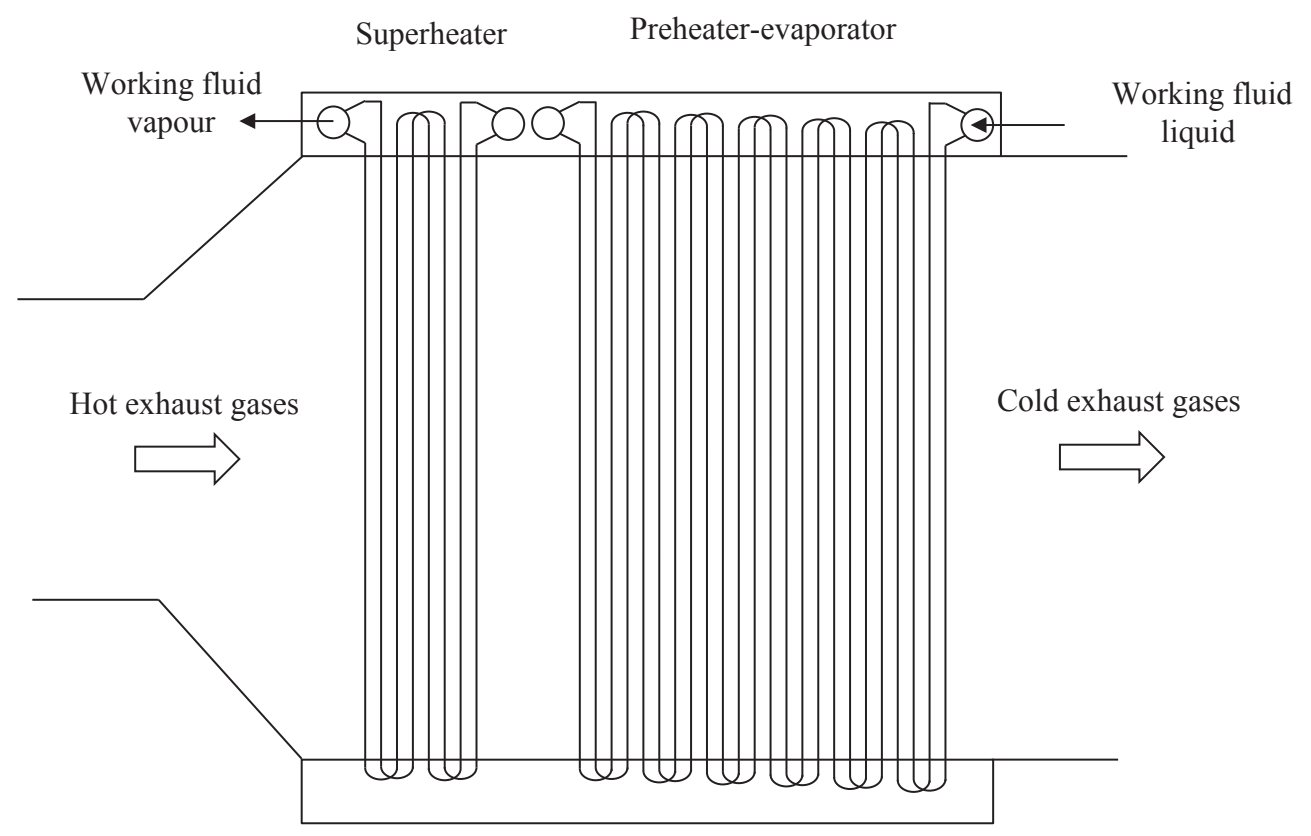

Figure 2: Layout of the once-through boiler serving the organic Rankine cycle power unit. The exhaust gases exiting the gas turbine heat up the working fluid which circulates first inside the preheater-evaporator, and, subsequently, in the superheater. 


\section{Methods} [52].

chanically coupled with a dedicated electric generator. The recuperator then decreases the energy contained in the superheated vapour exiting the expander by pre-heating the liquid before entering the OTB. The variable speed electric-driven pump and the sea-water cooled condenser complete the cycle. The working fluid is cyclopentane. This organic compound is widely adopted for ORC turbogenerators with maximum source temperature between $250-350^{\circ} \mathrm{C}$, see, e.g., Del Turco et al.

This part of the paper presents the adopted modelling language, see Section 3.1. Sections 3.2 and 3.3 are dedicated to the mathematical description of the models of the gas turbines and the organic Rankine cycle.

\subsection{The modelling language}

An effective way to build dynamic models is to use the fully modular approach of the equationbased, object-oriented modelling language Modelica [53]. Firstly, it allows to carry out the modelling task reliably and in a short time, as it leverages on existing libraries of reusable component models. Secondly, the equation-based approach of the language enables to easily customize the models for the specific requirements at hand.

The dynamic model of the combined cycle unit is developed using components from existing Modelica packages. The gas turbine sub-system model is built exploiting basic components included in the ThermoPower library [53]. The ORC system uses models from the Modelica ORC package [54], with suitable adaptations regarding the heat transfer coefficients and flow configuration inside the once-through boiler.

\subsection{The gas turbine}

Figure 3 shows the Modelica object diagram of the gas turbine. Compressors and turbines are multi-stage machines. These are modelled as zero-dimensional components using steady-state offdesign characteristics. The low and high pressure compressors are modelled employing the maps of axial compressors provided by Kurzke [55]. These maps, originally from Carchedi and Wood 


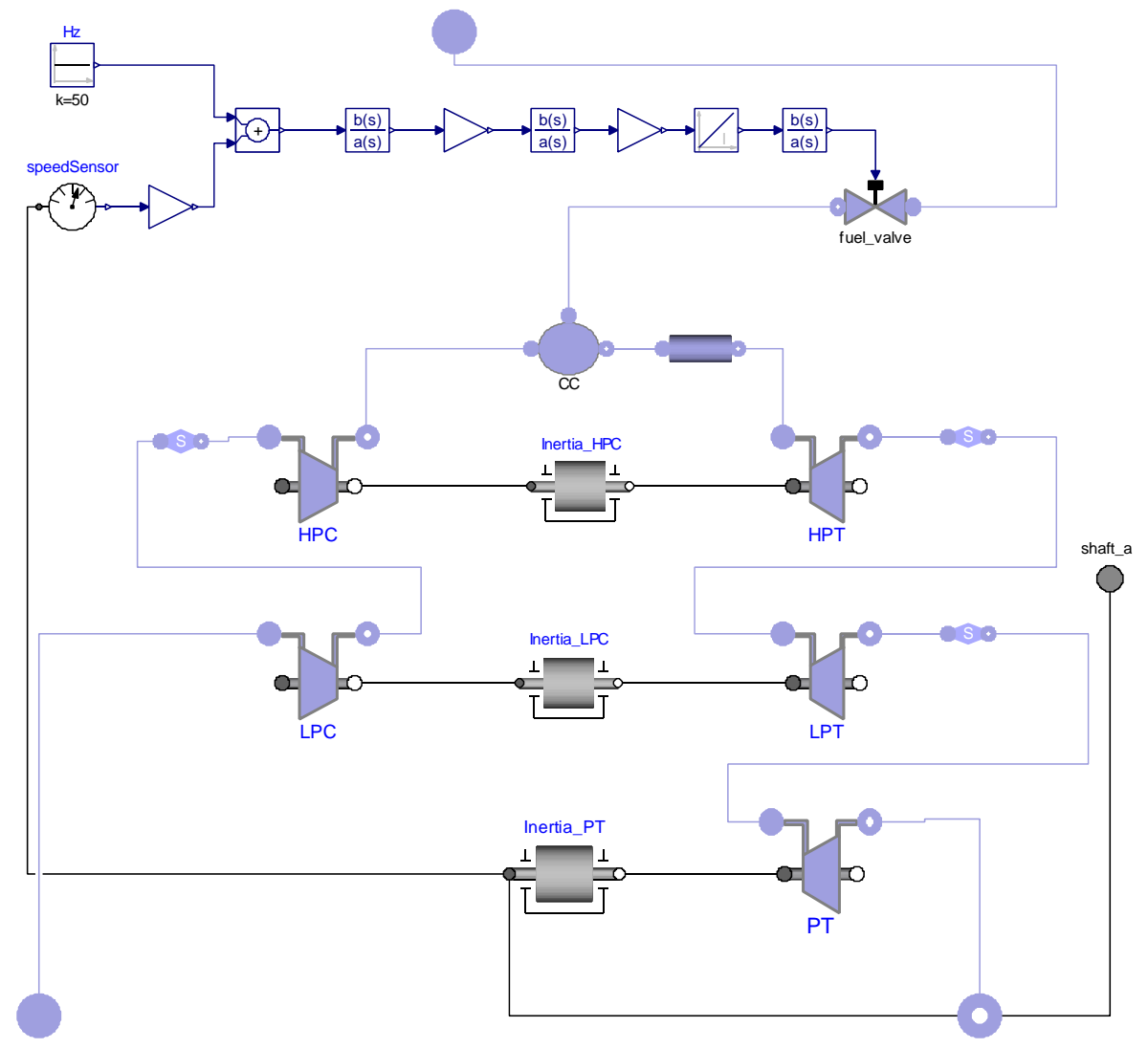

Figure 3: Object diagram of the gas turbine sub-system. 
[56], include tables that state values for flow coefficient, pressure ratio, isentropic efficiency and rotational speed for the complete operating range. The maps are scaled to represent the part-load characteristics of the axial machines following the method proposed by Kurzke [57].

The equation proposed by Stodola [58] is employed for modelling the low pressure turbine, the high pressure turbine and the power turbine. This equation expresses the relation between the inlet and outlet pressure of the expander with the mass flow rate and the turbine inlet temperature in off-design conditions. The part-load isentropic efficiency of the expanders is predicted using the correlation proposed by Schobeiri [59].

The combustion chamber (CC) is built assuming a complete and adiabatic combustion process. In the component, mass and energy conservation are expressed including the dynamic terms. As suggested by Camporeale et al. [60], the mass and the internal energy are computed using the thermodynamic properties of the combustion products exiting the combustion chamber. Furthermore, it is assumed that the combustion process and the mixing of air and fuel take place within a constant volume. The pressure drops are lumped in an external device assuming a quadratic dependence on the volumetric flow rate.

The shaft dynamic balance is used to model the dynamics of each spool. The values of the inertia of the rotating masses (shaft, blades, generator) and the volume of the combustion chamber are set according to data provided by the gas turbine manufacturer. The part-load performance of the electric generator is predicted using the equation proposed by Haglind and Elmegaard [61].

The topside of Figure 3 shows the control system of the SGT-500 engine as provided by the manufacturer. The compressors are not equipped with variable inlet guide vanes. Therefore, the load of the engine can be adjusted only using the fuel valve. See Pierobon et al. [62] for a more comprehensive description of the control system blocks.

\subsection{The organic Rankine cycle unit}

Figure 4 shows the top-level interface of the organic Rankine cycle module implemented in the Modelica language. Compared to the layout given in Figure 1, the object diagram includes the inertia of the turbine shaft, the components accounting for the frictional losses in the heat exchangers and the blocks setting the thermodynamic states of the air and fuel. The proportional- 
integral (PI) controller on the bottom-side of the diagram regulates the speed of the pump to keep the temperature of the exhaust gases constant. This operational strategy enables to avoid corrosion problems caused by the condensation of sulphuric acid vapour at any load condition and fuel composition. The input signal located on the top-right of Figure 4 sets the total power output of the combined cycle unit.

\subsubsection{The once-through boiler}

The model of the OTB is an extension of the generic evaporator model developed by Casella et al. [54]. Such models typically assume either co-current or counter-current flow configuration. Moreover, they do not resolve local fluid and wall temperatures inside tube bundles, which is a requirement for the current analysis. The flow configuration, i.e., the heat exchanger topology, has thus been extended and improved.

Figure 5(a) shows a top-view of the once-through boiler with a single longitudinal tube row. The OTB is recognized as a horizontal circular finned-tube bundle with counter-cross flow configuration. It is discretized in two dimensions, i.e., the exhaust gas flow direction (light purple arrows) and the organic fluid flow direction (blue arrows). The variables $N_{\text {tube }}$ and $N_{\text {pass }}$ are the number of cells per tube and longitudinal tubes, respectively. The temperature variations in the transverse direction of the finned-tube bundle are assumed negligible. Note that the total mass flow rate of the cold fluid is split in a series of circuits, which equal the number of transverse tubes, $N_{\mathrm{tr}}$, for the current tube circuitry. Similarly, the hot fluid is divided by the number of transverse tubes and the number of cells per tube.

Figure 5(b) shows the Modelica object diagram of the once-through boiler. The model uses a single one-dimensional organic fluid flow model (coldFluid) and $N_{\text {tube }}$ one-dimensional models (hotFluid) for the exhaust gases. The cold fluid model is connected to its pipe wall capacitance (tubeWalls) and a heat exchanger topology model (extCrossFlow). The latter essentially connects the thermal heat ports (orange rectangles in Figure 5(b)) of each finite volumes (dashed red rectangles in Figure 5(a)), i.e., the hot fluid wall boundary with the external pipe boundary.

The tube wall model includes a one-dimensional dynamic heat balance equation in the radial direction for each finite volumes. The model neglects the small conductive thermal resistance. The 


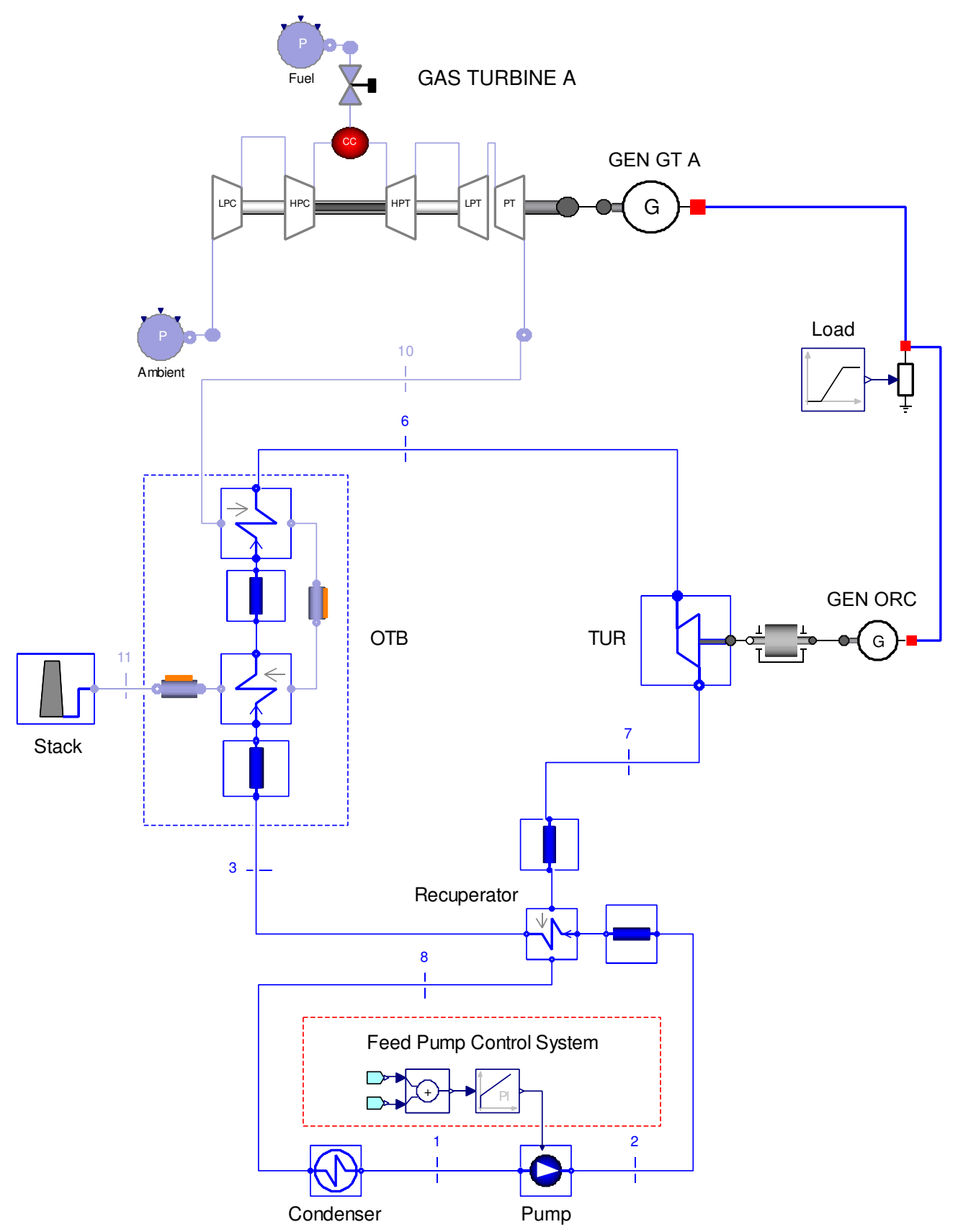

Figure 4: Object diagram of the organic Rankine cycle turbogenerator. 


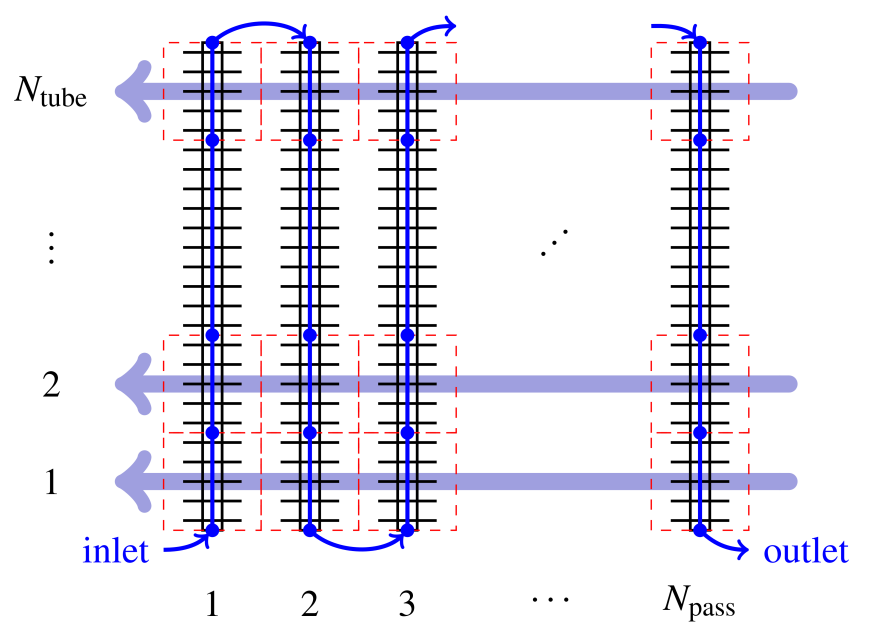

(a)

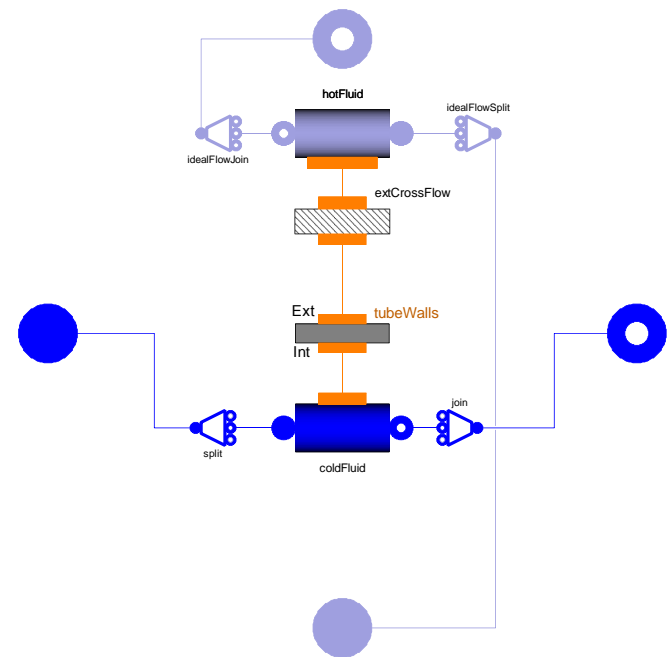

(b)

Figure 5: Extended ThermoPower heat exchanger model. 5(a) Top-view of the once-through boiler showing the discretization method. 5(b) Modelica object diagram.

1 flow models contain one-dimensional dynamic mass and energy balance equations, discretized by 2 the finite volume method, assuming a uniform pressure distribution. The relatively small friction losses are lumped in an external component. As for the combustion chamber, the pressure drops 4 are estimated assuming a quadratic dependency on the volumetric flow rate. A more in-depth 5 description of the tube wall and flow models can be found in Casella et al. [54]. Appendix A 6 reports the equations used for the estimation of the heat transfer coefficients in the once-through 7 boiler.

\section{3.3.2. The supersonic turbine}

For MW-size ORC power plants, the expander is a one- or two-stage axial turbine. The pressure ratio of each stage is relatively high (20). This implies that the flow at the outlet of the first stage is usually supersonic. The turbine is modelled as an equivalent chocked de Laval nozzle, whose throat flow passage area is the sum of the throat areas of the nozzles of the first stator row.

An isentropic expansion is assumed from the inlet section to the throat, where sonic conditions are attained. The corresponding system of equations is listed below. 


$$
\left\{\begin{array}{l}
s_{i n}=s\left(p_{T, i n}, T_{T, i n}\right) \\
h_{S, t h}=h_{T, i n}\left(p_{T, i n}, T_{T, i n}\right)-\frac{1}{2} \cdot c\left(h_{S, t h}, s_{i n}\right)^{2} \\
\dot{m}=\rho_{S, t h}\left(h_{S, t h}, s_{i n}\right) \cdot c\left(h_{S, t h}, s_{i n}\right) \cdot A_{t h}
\end{array}\right.
$$

where $s_{i n}$ is the specific entropy at the turbine inlet. The subscripts "S,th" and "T,in" indicate static conditions in the throat section and total conditions in the expander inlet section (i.e. total inlet pressure $p_{T, \text { in }}$ and total temperature $\left.T_{T, i n}\right)$, respectively. The enthalpy and the speed of sound are represented with $h$ and $c$, respectively. The variables $\dot{m}, \rho$ and $A_{t h}$ are the mass flow rate through the nozzle, the density and the flow passage area. The throat passage area $A_{t h}$ is obtained from the design calculation. During off-design conditions, the relation between the mass flow rate and the turbine inlet conditions is expressed by Equation system 1. The isentropic efficiency at part-load is predicted using the correlation proposed by Schobeiri [59].

\subsubsection{The other components}

Figure 6 shows the object diagram of the recuperator feeding the ORC power module. Starting from the topside of the figure, the models of the one-dimensional flow for the vapour side (hotFluid), the counter-current topology block (counterCurrent), the tube walls (tubeWalls and the one-dimensional flow representing the liquid side (coldFluid) are shown.

The counter-current establishes the topological correspondence between the control volumes of the tube metal walls and those of the working fluid on the hot and cold side. The flow models utilize one-dimensional dynamic mass and energy balance equations (discretized following the finite volume method, and assuming a uniform pressure distribution) and the static momentum balances (lumped at both ends of the component). The tube metal wall is modelled by a one-dimensional dynamic heat balance equation, also discretized in finite volumes, neglecting the conductive thermal resistance [53]. In the present case, the heat transfer coefficient is mainly controlled by the vapour side. The liquid side heat transfer coefficient is thus specified to be sufficiently large. The overall resistance is thus assumed equal to that of the vapour. At off-design conditions the heat transfer coefficient is computed by the correlation proposed by Incropera et al. [63].

The condenser is trivially modelled as a fixed pressure component. This is justified considering 


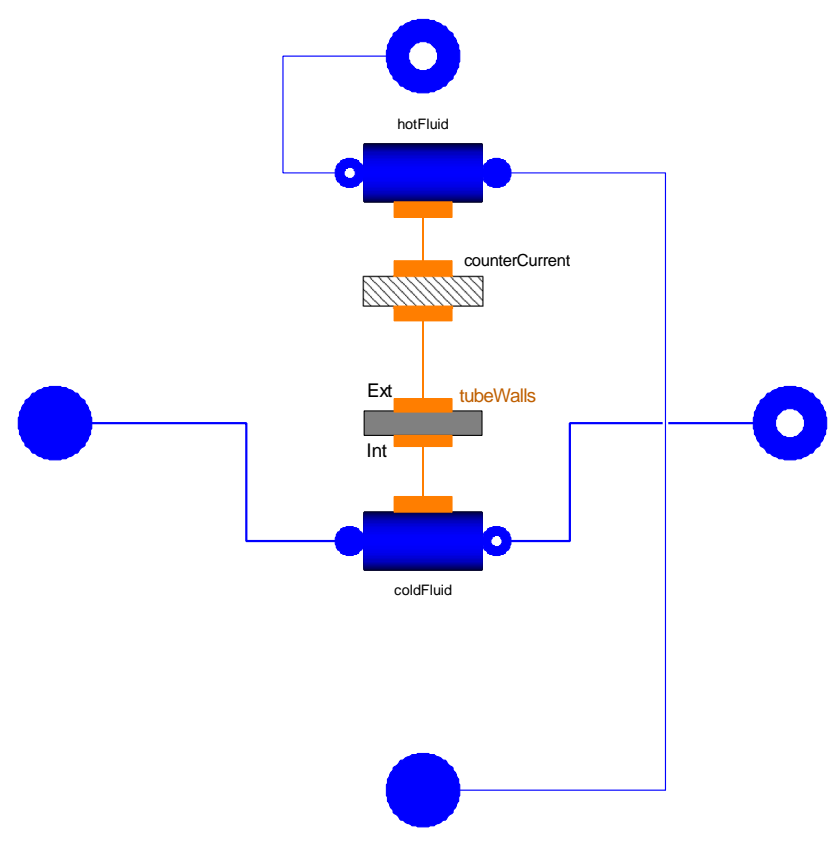

Figure 6: Object diagram of the organic Rankine cycle shell-and-tube recuperator model.

the large availability of cooling sea-water. The cooling circuit is thus controlled in such a way that the condenser pressure is nearly constant. The pump model is based on a head-volume flow curve derived by fitting the data of a centrifugal pump projected for similar design specifications.

The downside of Figure 4 shows the control system of the ORC unit. As mentioned, the platform has a stand-alone system. Given that the topping units have the fastest load response, the control of the network frequency is managed by the gas turbine itself. Conversely, the goal of the control system of the ORC unit is to maximize the waste heat recovery.

This task can be fulfilled by varying the pump speed to control the exhaust gas temperature at the once-through boiler outlet and operating in sliding pressure mode. This temperature should be as low as possible, yet high enough to prevent acid condensation. The proportional-integral controller is tuned to reach the minimum settling time of the controlled variable, to prevent speed overshooting and obtain well-damped responses for all variables.

\subsubsection{Model assumptions}

An in-house simulation tool is used to design the ORC unit [48, 49]. Table B.3 in Appendix B lists the organic Rankine cycle state points. Figure B.12 shows the $T$-s diagram with the ther- 
modynamic state points and the saturation dome of the ORC process. Table B.4 lists the main equipment parameters inserted in the model.

The thermodynamic and transport properties of the working fluid are computed according to the models implemented in the open-source software developed by Bell et al. [64].

It is assumed that the operational range of the gas turbine spans from $20 \%$ to $100 \%$. The minimum load of the engine is thus $3 \mathrm{MW}$. This lower boundary gives a reasonable margin against chocking and surging of the compressors serving the gas turbine.

The time for the gas turbine trip, i.e., the period needed to pass from a certain load to zero, is set equal to $10 \mathrm{~s}$. The system operates so that gas turbine A and the ORC unit share the load with the engine B. The third gas turbine is on stand-by. The test case implies that, at a given time, the engine B trips. The combined cycle unit counteracts by ramping up its load matching the total power request.

Considering the experimental measurements carried out by Pasetti et al.[36] and Ginosar et al. [65], a maximum temperature $\left(T_{c, \max }\right)$ for the organic compound of $270{ }^{\circ} \mathrm{C}$ is assumed. The tests are performed at different ramp rates $\left(0.3-1.0 \mathrm{MW} \cdot \mathrm{s}^{-1}\right)$ to estimate the frequency and the temperature trends of cyclopentane.

\section{Model validation}

The models of the gas turbine and of the ORC turbogenerator are validated in Section 4.1 using proprietary experimental data. Section 4.2 presents the verification of the once-through boiler model, on the basis of information available in open literature.

\subsection{The gas turbine and ORC unit}

The steady-state part-load performance of the gas turbine is compared with the off-design characteristics given by the gas turbine manufacturer. The fuel and exhaust gas mass flow rate, the exhaust gas temperature and the pressure at the combustion chamber outlet are considered in the validation process. The largest mismatch is observed for the fuel mass flow rate. Its relative error is about $3 \%$ from $60 \%$ to $100 \%$ load and $15 \%$ from $10 \%$ and $60 \%$. For the dynamic validation, the entire power system installed on Draugen platform is considered. The dynamic model of the 
plant was validated using the operational data of the oil and gas facility. See Pierobon et al. [62] for a more comprehensive description of the validation process. Note that the model can predict the network frequency with a relative error lower than $1 \%$ during the trip of one engine [62]. The gas turbine dynamic model is thus capable to reproduce the steady-state and the dynamic characteristics of the engines with satisfactory accuracy over the entire range of loads.

The model of the ORC system is composed by software objects taken from a library developed to model a $150 \mathrm{~kW}$ ORC system using toluene as the working fluid. The model was successfully validated for transient operation against experimental data as discussed in Casella et al. [54]. The developed models are therefore deemed reliable, considering the similarity of the application at hand with the one presented in the cited reference. Furthermore, it was verified that the nameplate and off-design operating points predicted by the model are consistent with those computed by the simulation tool [66] utilized to design the system.

\subsection{The once-through boiler}

The OTB model described in Section 3.3.1 was verified, for the design-point condition, with the results for the heat recovery steam generator (HRSG) designed in Dumont and Heyen [67]. The HRSG topology, geometry and operating conditions were used to parametrize the Modelica model. The deviation for the heat flux is less then $1 \%$. The outlet temperature of the steam and exhaust gases differ by $3 \%$ and $7 \%$, respectively. The model discrepancies are due to the uncertainties on the fin thickness and efficiency assumed in the reference model and on the estimation of the physical properties of the fluids.

As further proof of the model accuracy, a comparison with a cross-flow heat exchanger model available in Thermal Power library [68] was performed at off-design conditions. The topology, geometry, correlations and number of finite volumes are equivalent in both models. The validation highlighted a difference smaller than $2 \%$ in all process variables.

The model can thus reproduce the steady-state part-load characteristics of the once-through boiler with satisfactory accuracy, given the in-depth verification using commercial tools and data. 


\section{Results and discussion}

Figure 7 shows the temperature trends of cyclopentane at the outlet section of the once-through boiler for different load changes. Table 2 reports the peak temperature reached by the metal wall 4 and organic compound during each transient event.

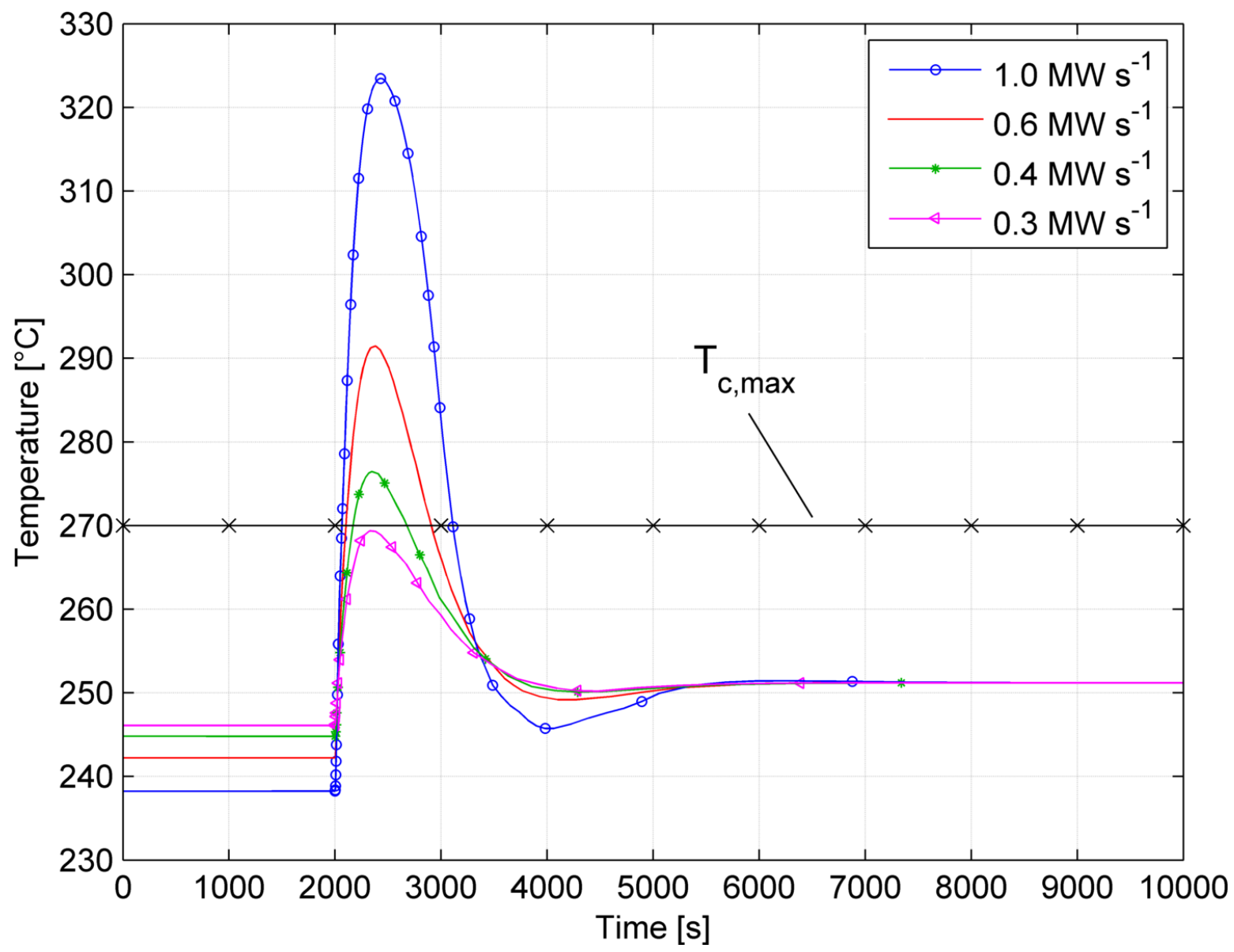

Figure 7: Dynamics of the temperature at the outlet section of the once-through boiler during load changes.

5

The results indicate that the temperature exceeds $T_{c, \max }$ for ramp rates higher than $0.3 \mathrm{MW} \cdot \mathrm{s}^{-1}$. To estimate the long-term effects on the thermochemical stability of the fluid, the amount of time at which the fluid operates under this critical conditions has to be computed. The time is around 8 minutes for a ramp rate of $0.4 \mathrm{MW} \cdot \mathrm{s}^{-1}$ ) and 18 minutes for $1.0 \mathrm{MW} \cdot \mathrm{s}^{-1}$.

Offshore power systems connected to a standalone electric grid have strict constraints on the frequency tolerances and recovery time. The frequency undershooting (overshooting) is the mini- 
Table 2: Power produced by the GTs and ORC unit before the failure of GT B. The metal wall and fluid temperatures in the hottest point of the heat exchanger are also listed.

\begin{tabular}{ccccc}
\hline $\begin{array}{c}\text { Load GT A + ORC } \\
{[\mathrm{MW}]}\end{array}$ & $\begin{array}{c}\text { Load GT B } \\
{[\mathrm{MW}]}\end{array}$ & $\begin{array}{c}\text { Ramp rate } \\
{\left[\mathrm{MW} \cdot \mathrm{s}^{-1}\right]}\end{array}$ & $\begin{array}{c}\mathrm{T}_{\text {wall }} \\
{\left[{ }^{\circ} \mathrm{C}\right]}\end{array}$ & $\begin{array}{c}\mathrm{T}_{\text {cyclopentane }} \\
{\left[{ }^{\circ} \mathrm{C}\right]}\end{array}$ \\
\hline 9 & 10 & 1.00 & 331.3 & 323.4 \\
10 & 9 & 0.90 & 324.9 & 316.0 \\
11 & 8 & 0.80 & 318.3 & 308.0 \\
12 & 7 & 0.70 & 310.8 & 299.2 \\
13 & 6 & 0.60 & 304.2 & 291.4 \\
14 & 5 & 0.50 & 297.4 & 283.5 \\
15 & 4 & 0.40 & 291.2 & 276.4 \\
16 & 3 & 0.30 & 284.9 & 269.3 \\
\hline
\end{tabular}

1 mum (maximum) value reached by the frequency during a load change, expressed as a percentage

The grid specifications have a maximum undershooting of $5 \%$. Table 2 and Figure 8 show that than $5 \%$. In the other cases, the dynamic parameters satisfy the requirements. The fastest load change that fulfils that grid specification and ensures the thermochemical stability of the working fluid is thus $0.3 \mathrm{MW} \cdot s^{-1}$.

In order to preserve the fluid stability, a spray attemperator system is added to the plant layout, see Figure 9. This device is used to limit the temperature in the superheating section of the oncethrough boiler. The saturated vapour exiting the preheater-evaporator section is collected into a separator. The measurable temperature nearest to the temperature of the metal wall and the working fluid in the terminal part of the OTB is the turbine inlet temperature $T_{6}$. If this quantity exceeds the maximum value imposed by the user (in this case $270^{\circ} \mathrm{C}$ ), the spray attemperator system injects into the separator (see Figure 9) subcooled cyclopentane extracted from the pump outlet. A 


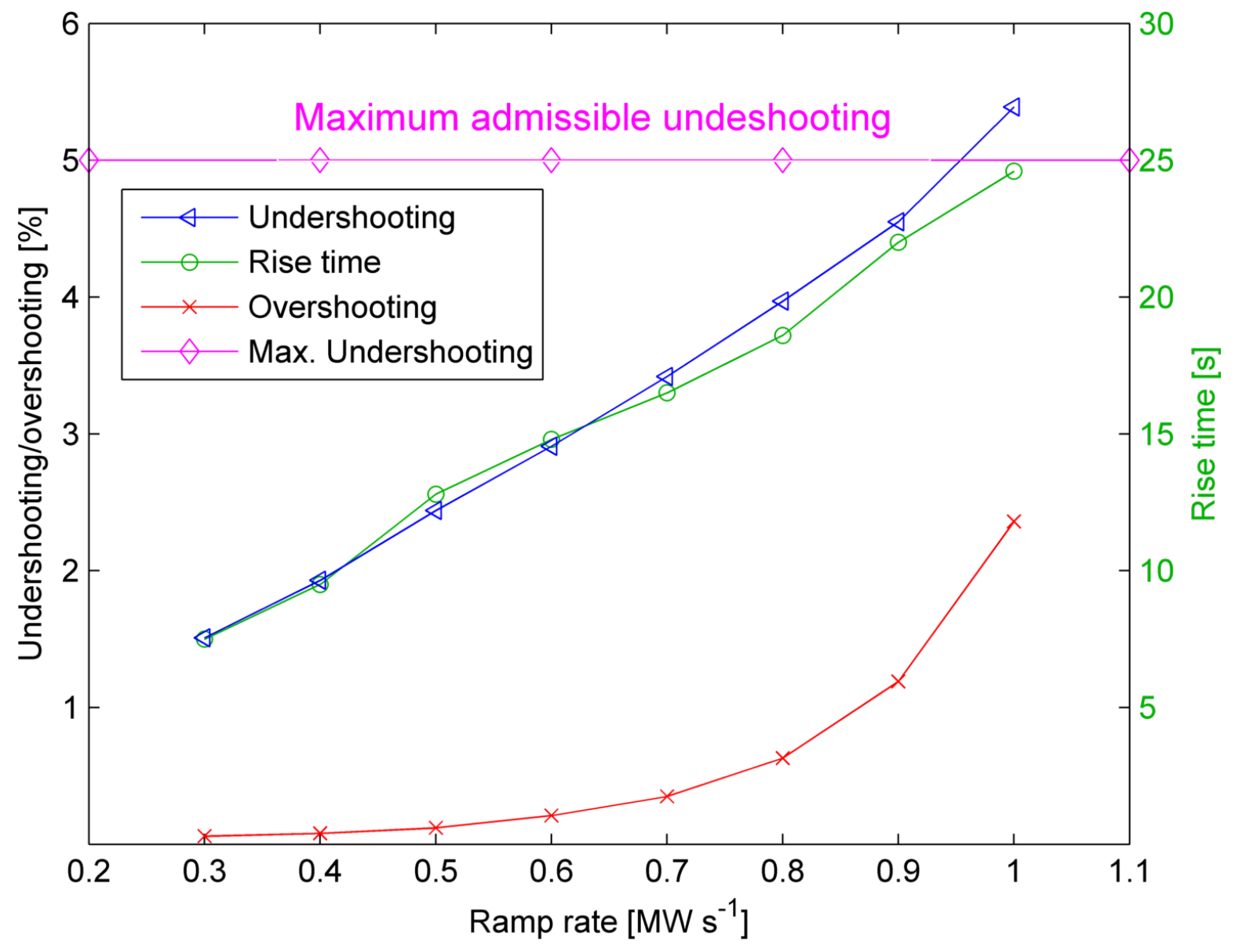

Figure 8: Dynamic metrics as a function of the load change. 


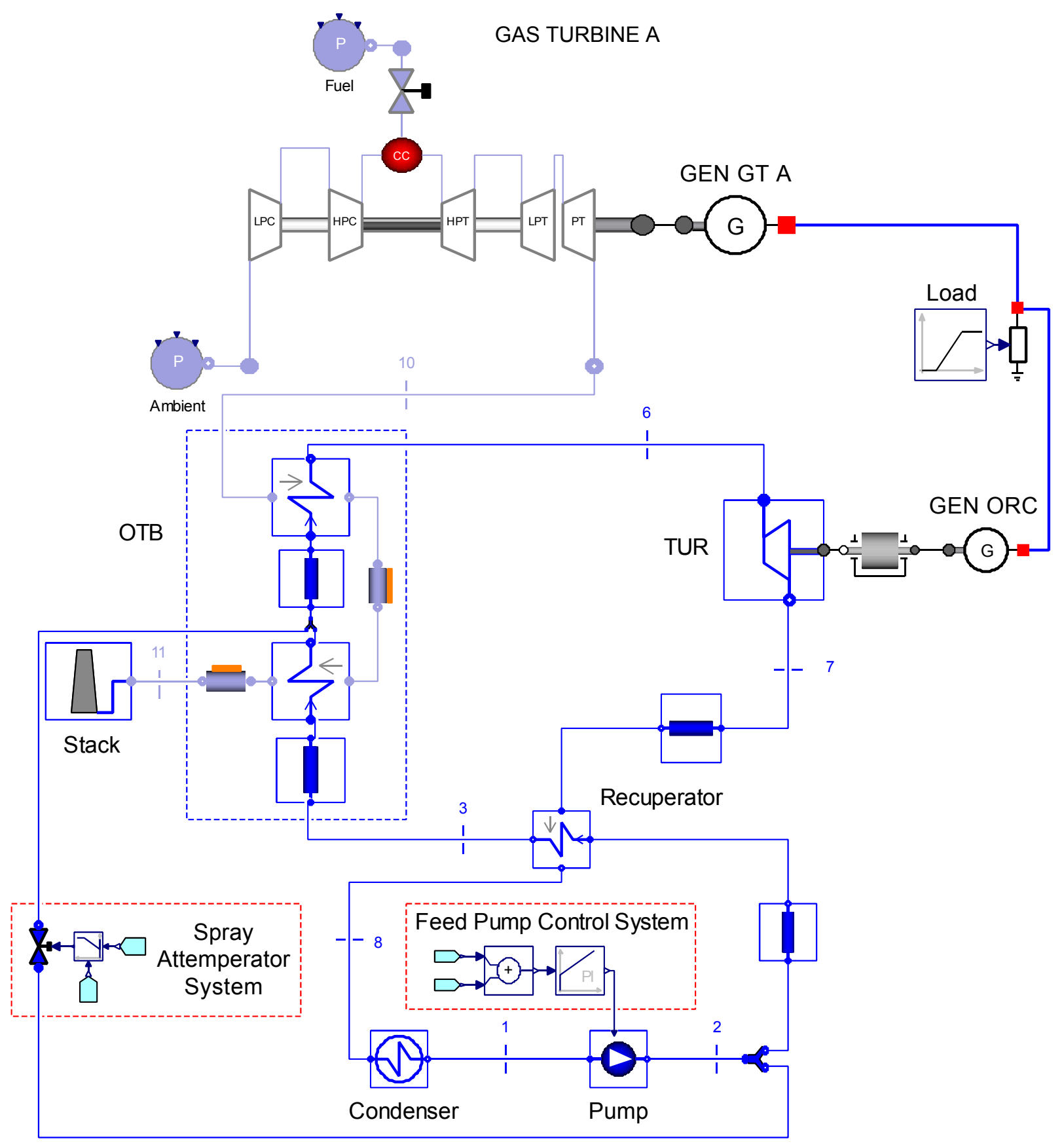

Figure 9: Object diagram of the combined cycle unit. The controller and the spray attemperator system are also shown. 
1 properly tuned PI controller regulates the mass flow rate extracted using a dedicated valve. In the 2 PI controller, the measured temperature $T_{6}$ is compared with the reference value $T_{c, \max }$. The signal 3 is then transmitted to the attemperator valve. As for the previous plant configuration (Figure 4), 4 the pump speed is controlled to maintain the exhaust gas temperature exiting to the once-through 5 boiler at the design-point value.

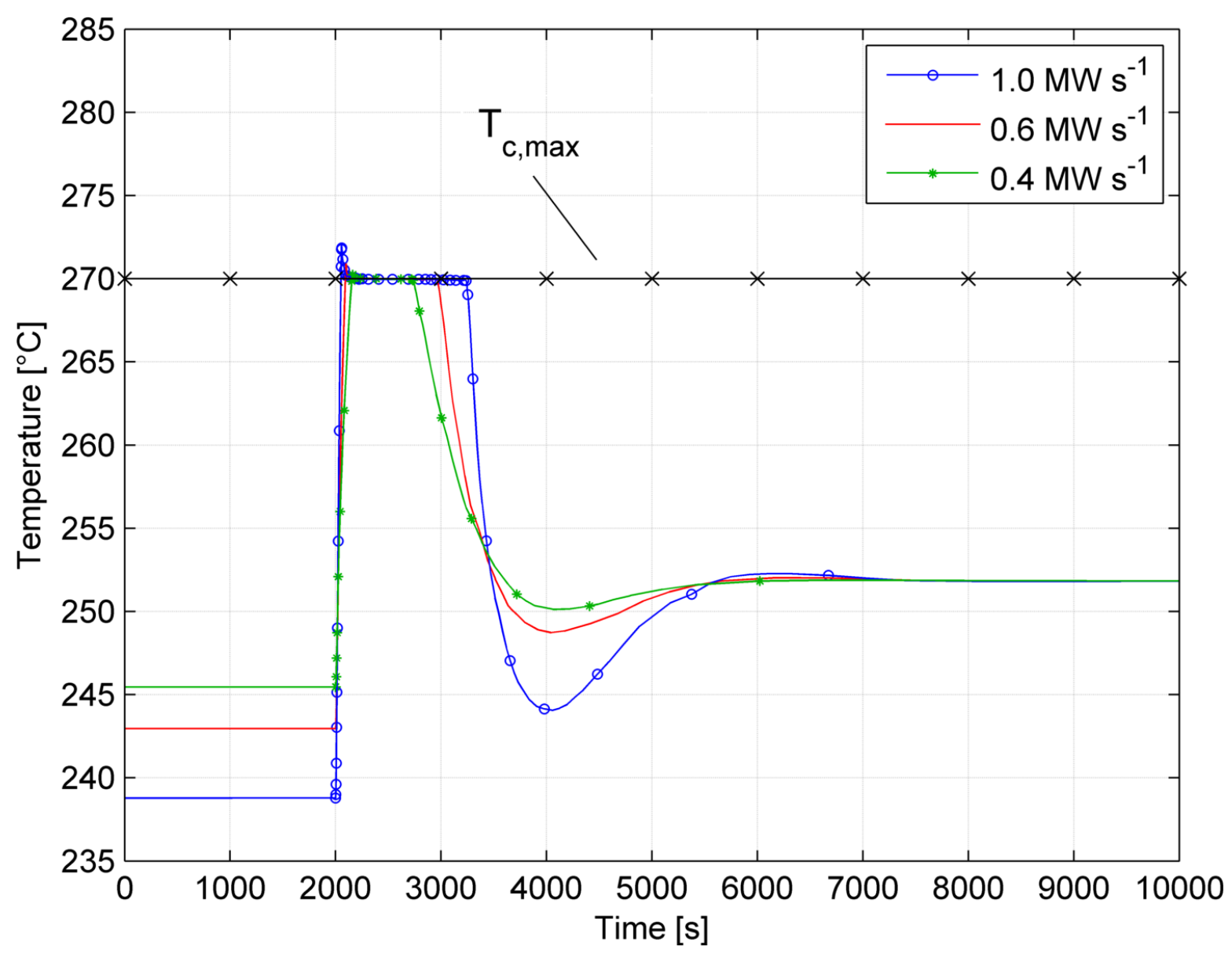

Figure 10: Dynamics of the temperature at the outlet of the once-through boiler using the spray attemperator system.

Figure 10 shows the trend of the working fluid temperature at the heat exchanger outlet with 7 the new control system. A ramp rate of $0.3 \mathrm{MW} \cdot \mathrm{s}^{-1}$ is not analysed as the activation of the spray 8 attemperator system is not needed, see Figure 7. The plots show that, with the exception of the first instants of the transient, the controller can maintain the temperature at the reference value. This prevents the hot spot formation and working fluid degradation.

For the sake of completeness, a comparison between the results obtained with and without the 
1 spray attemperator system is presented (see Figure 11). The purpose is to demonstrate that the 2 introduction of the attemperator module does not modify significantly the dynamic response of 3 the plant. The reference test case is a ramp rate of $0.6 \mathrm{MW} \cdot \mathrm{s}^{-1}$.

4 Figure 11(a) demonstrates that the attemperator system does not affect the frequency trend. 5 Figure 11(b) shows the variation of the mass flow rate entering the once-through boiler, while 6 Figure 11(c) reports the pump speed. The spray attemperator entails a reduction of the mass flow 7 rate. In fact, a fraction of the working fluid leaving the pump deviates towards the attemperator 8 valve to be injected into the separator. Maximum differences of around $1.0^{\circ} \mathrm{C}$ are observed for the 9 temperature of the exhaust gases exiting the OTB and for the outlet temperature on the cold-side 10 of the recuperator, see Figure 11(d) and Figure 11(e). Finally, Figure 11(f) shows the dynamics 11 of the turbine inlet pressure. The implementation of the attemperator system implies a pressure 12 reduction of around $20 \mathrm{kPa}$. 


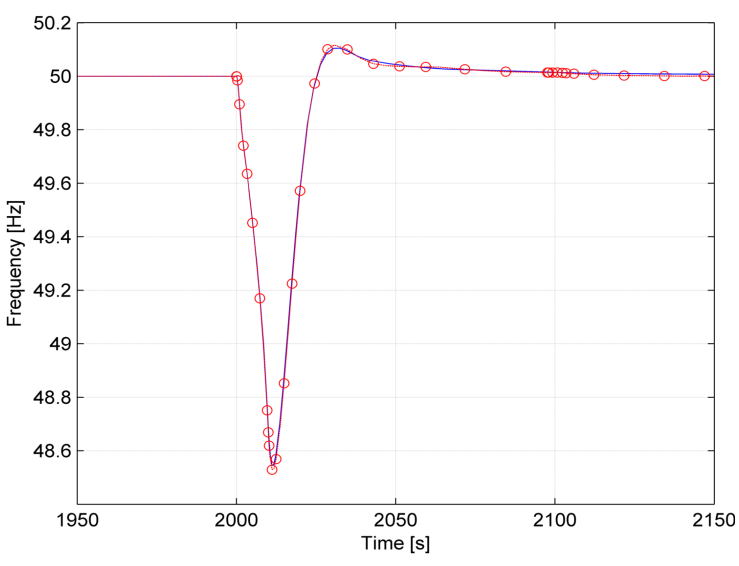

(a) Grid frequency

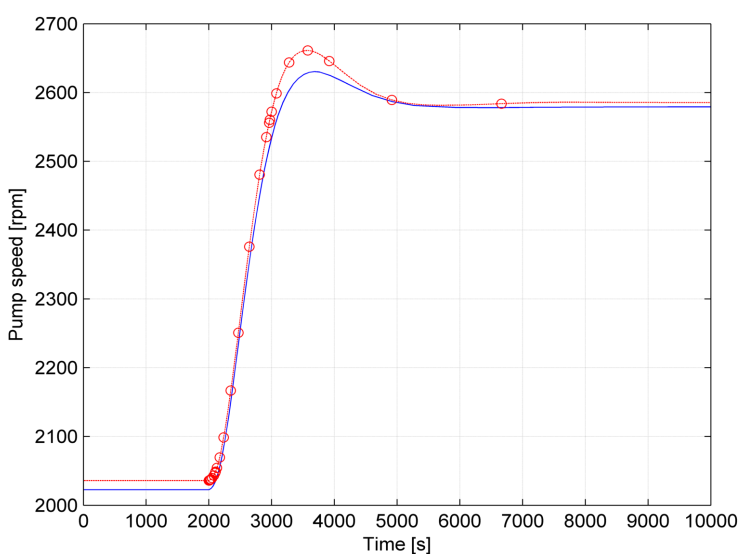

(c) Pump speed

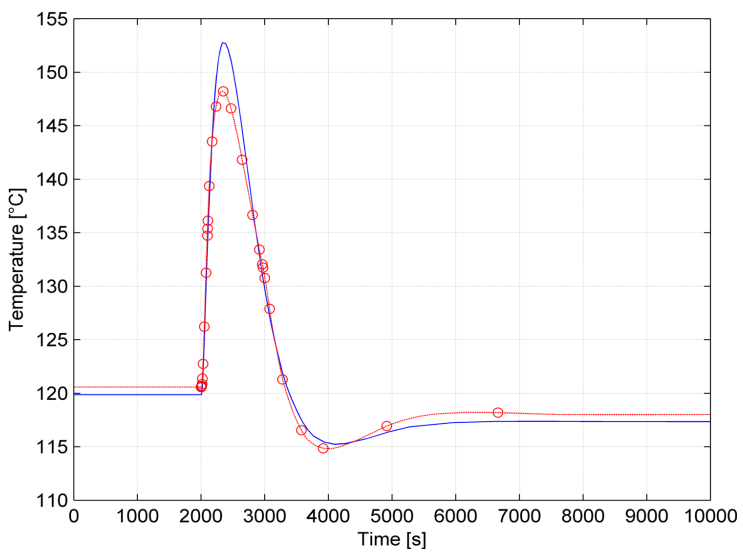

(e) OTB cyclopentane inlet temperature

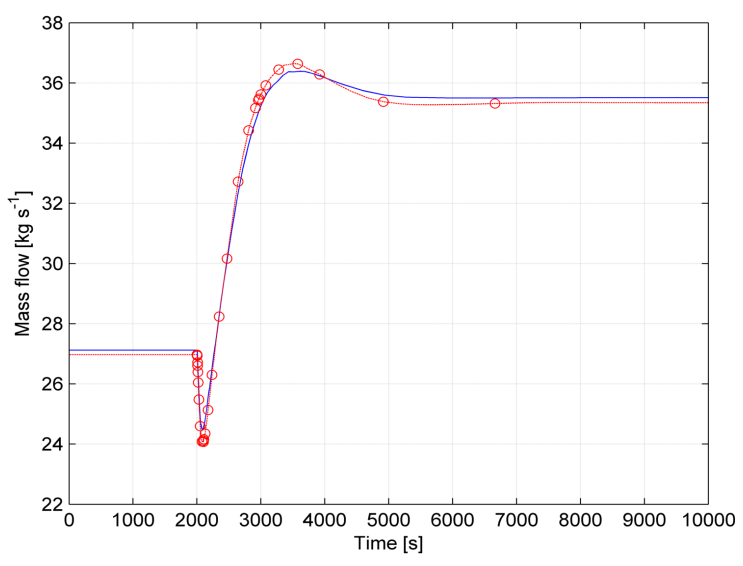

(b) Pump mass flow rate

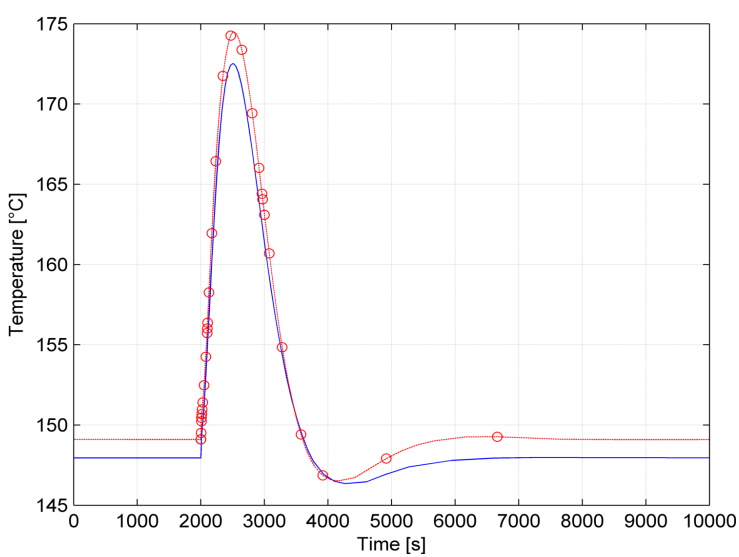

(d) OTB exhaust gases outlet temperature

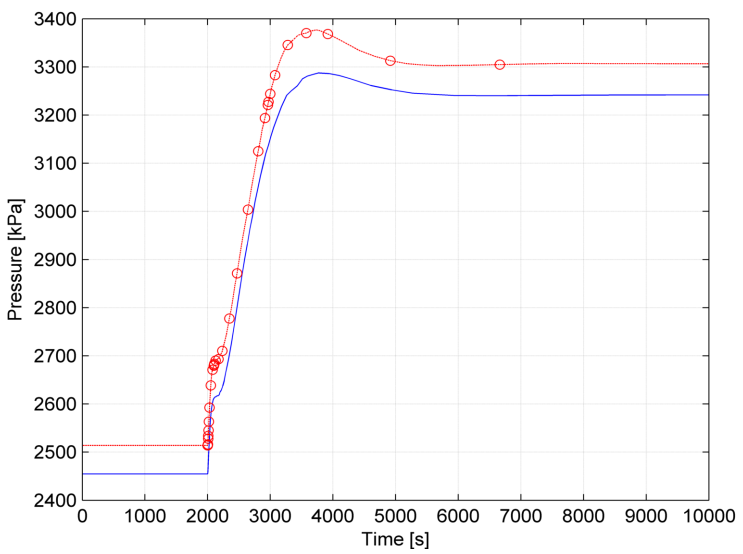

(f) OTB cyclopentane inlet pressure

Figure 11: Dynamics of the combined cycle unit. The dotted line refers to the parameters of the plant with the spray attemperator system. 


\section{Conclusions}

2 This paper presents a transient analysis that identifies critical dynamic events (hot spots) and a 3 methodology to avoid fluid decomposition in ORC boilers.

4 Dynamic simulations performed at different ramp rates highlight that the most critical com5 ponent is the once-through boiler. Simulation results suggest that the temperature of the working 6 fluid exceeds the maximum admissible value for ramp rates higher than $0.3 \mathrm{MW} \cdot \mathrm{s}^{-1}$. Such event 7 becomes more critical during sharp load changes $\left(>1.0 \mathrm{MW} \cdot \mathrm{s}^{-1}\right)$, due to the longer periods $(\approx 20$ $8 \mathrm{~min}$ ) of local overheating of the fluid.

9 This work demonstrates that the insertion of a spray attemperator module is a viable solution to tackle such operational issue. This device coupled with a properly tuned control system can maintain the temperature at the terminal section of the once-through boiler under a predefined 2 threshold. This system does not affect significantly the dynamics of the process variables. Moreover, it eliminates the risk of fluid decomposition during aggressive load changes by injecting a fraction of the liquid exiting the pump in the superheating section.

The proposed approach and the relative solution are readily applicable without loss of generality to other power systems integrating organic Rankine cycle modules with gas turbines, boilers (fed by fossil and renewable fuels), fuel cells and solar units. 
1 Appendix A. Heat transfer correlations 9 adopted

This appendix reports the single phase and two-phase boiling heat transfer correlations used to simulate the dynamics of the once-through boiler, see Section 3.3.1. Note that a continuous transition is required at the phase boundaries to ensure a smooth first derivative when entering the two-phase flow regime. In this work, we used the Stepsmoother function provided by the Modelica.Fluid.Dissipation library [69], i.e., between the vapour qualities $0 \leq x<0.05$ and $0.95<x \leq 1$.

For single phase turbulent flow at $\operatorname{Re}>3000$, the correlation proposed by Gnielinski [70] is

$$
\mathrm{Nu}=\frac{\left(f_{D} / 8\right)(\mathrm{Re}-1000) \operatorname{Pr}}{1+12.7\left(f_{D} / 8\right)^{0.5}\left(\operatorname{Pr}^{2 / 3}-1\right)}
$$

where the Nusselt number is $\mathrm{Nu}=h \cdot d / k$. The Darcy-Weisbach friction factor is computed according to Petukhov [71].

$$
f_{D}=(0.7904 \ln (\mathrm{Re})-1.64)^{-2}
$$

For laminar flow ( $\operatorname{Re}<2300$ ), the Nusselt number is equal to 3.66 assuming a constant wall temperature. A simple smooth transition function is used between the laminar and turbulent Nusselt numbers.

For two-phase flow, the correlation proposed by Shah [72] is used to compute the heat transfer coefficient in local two-phase forced convective boiling. This correlation takes the largest value between the nucleate boiling heat transfer coefficient $h_{n b}$ and the convective boiling heat transfer coefficient $h_{c b}$. The correlation is as follows:

For horizontal flow calculate the dimensionless parameter $N$ by

$$
\begin{array}{ll}
N=C_{o} & \mathrm{Fr}_{L}>0.04 \\
N=0.38 \mathrm{Fr}_{L}{ }^{-0.3} C_{o} & \mathrm{Fr}_{L} \leq 0.04
\end{array}
$$


1 For the vertical flow, use Equation A.3 for all values of the liquid Froude number $\mathrm{Fr}_{L}$. $\mathrm{The}$ 2 liquid Froude number and the dimensionless parameter $C_{o}$ is given by

$$
\begin{gathered}
\operatorname{Fr}_{L}=\frac{G^{2}}{\rho_{L}^{2} g d} \\
C_{o}=\left(\frac{1-x}{x}\right)^{0.8}\left(\frac{\rho_{G}}{\rho_{L}}\right)^{0.5}
\end{gathered}
$$

3 when $N>1$, calculate $h_{n b}$ from

$$
\begin{array}{ll}
h_{n b}=230 h_{L} \mathrm{Bo}^{0.5} & \text { Bo }>0.0003 \\
h_{n b}=h_{L}\left(1+46 \mathrm{Bo}^{0.5}\right) & \text { Bo } \leq 0.0003
\end{array}
$$

4 when $1>N \geq 0.1$, calculate $h_{n b}$ from

$$
h_{n b}=h_{L} F \mathrm{Bo}^{0.5} \exp \left(2.74 N^{-0.1}\right)
$$

${ }_{5}$ when $N<0.1$, calculate $h_{n b}$ from

$$
h_{n b}=h_{L} F \mathrm{Bo}^{0.5} \exp \left(2.47 N^{-0.15}\right)
$$

6 where $h_{L}$ is the liquid heat transfer coefficient calculated by the Dittus-Boelter correlation

$$
\begin{gathered}
\mathrm{Nu}_{L}=0.023 \operatorname{Re}_{L}^{0.8} \operatorname{Pr}_{L}^{0.4} \\
h_{L}=\mathrm{Nu}_{L} \frac{k_{L}}{d} \\
\operatorname{Re}_{L}=\frac{G(1-x) d}{\mu_{L}} \\
\operatorname{Pr}_{L}=\frac{\mu_{L} c_{p, L}}{k_{L}}
\end{gathered}
$$

7 The boiling number Bo is defined as

$$
\text { Bo }=\frac{q^{\prime \prime}}{G h_{\mathrm{LG}}}
$$


1 and the constant $F$ is determined as follows

$$
\begin{array}{ll}
F=14.7 & \text { Bo }>0.0011 \\
F=15.43 & \text { Bo } \leq 0.0011
\end{array}
$$

2 The convective boiling heat transfer coefficient $h_{c b}$ is computed by

$$
h_{c b}=h_{L} \frac{1.8}{N^{0.8}}
$$

3 Finally, the highest value of the two $\left(h_{c b}\right.$ and $\left.h_{n b}\right)$ is chosen for the heat transfer coefficient $h$.

$4 \quad$ The heat flow rate in each cold fluid cells is then computed by the Newton's law of cooling as

$$
q=h A\left(T_{w i}-T_{c}\right)
$$

5 where subscripts "wi" and "c" denote the inner wall and cold fluid, respectively. The variable $A$ is 6 the inner tube surface area of a single cell.

$7 \quad$ The gas-side heat transfer coefficient and the fin efficiency are computed with the correlations 8 given for staggered circular finned-tubes in the Verein Deutscher Ingenieure Heat Atlas [73].

$9 \quad$ The Nusselt number based on the outer tube diameter $D$ is computed by

$$
\mathrm{Nu}=0.38 \operatorname{Re}_{D}^{0.6}\left(\frac{A}{A_{\mathrm{t} 0}}\right)^{-0.15} \operatorname{Pr}^{1 / 3}
$$

$$
\begin{gathered}
\eta_{f}=\frac{\tanh X}{X} \\
X=\varphi \frac{D}{2} \sqrt{\frac{2 h}{k_{f} \delta}}
\end{gathered}
$$


1 where $h$ is the heat transfer coefficient, $k_{f}$ is the thermal conductivity of the fins, and $\delta$ is the fin

2 thickness. For circular non-conic fins $\varphi$ is computed by

$$
\varphi=\left(\frac{D_{f}}{D}-1\right)\left[1+0.35 \ln \left(\frac{D_{f}}{D}\right)\right]
$$

${ }_{3}$ where $D_{f}$ denotes the fin diameter. Finally, the overall surface fin efficiency is calculated by

$$
\eta_{o}=1-\frac{A_{f}}{A}\left(1-\eta_{f}\right)
$$

4 where $A_{f}=A-A_{\mathrm{t} 0}$, i.e the finned surface area.

5 The heat flow rate in each hot fluid cell is computed by Newton's law of cooling similar to the 6 cold fluid, but including the overall surface fin efficiency as

$$
q=\eta_{o} h A\left(T_{w o}-T_{h}\right)
$$

7 where subscripts "wo" and "h" denote the outer wall and hot fluid, respectively. Note that $T_{c}$ and ${ }_{8} T_{h}$ in equation A.19 and A.25 are taken as the cell center average value. 


\section{Appendix B. Design-point analysis results}

2 The organic Rankine cycle state points, the related $T$-s diagram with the thermodynamic state 3 points and the main equipment parameters included into the ORC model are reported.

Table B.3: Organic Rankine cycle state points

\begin{tabular}{cccccc}
\hline Point & $\begin{array}{c}\mathrm{T} \\
{\left[{ }^{\circ} \mathrm{C}\right]}\end{array}$ & $\begin{array}{c}\mathrm{p} \\
{[\mathrm{kPa}]}\end{array}$ & $\begin{array}{c}\rho \\
{\left[\mathrm{kg} \cdot \mathrm{m}^{-3}\right]}\end{array}$ & $\begin{array}{c}\mathrm{h} \\
{\left[\mathrm{kJ} \cdot \mathrm{kg}^{-1}\right]}\end{array}$ & $\begin{array}{c}\mathrm{s} \\
{\left[\mathrm{kJ} \cdot \mathrm{kg}^{-1} \cdot \mathrm{K}^{-1}\right]}\end{array}$ \\
\hline 1 & 50.00 & 103.83 & 715.16 & 1.44 & 0.0044 \\
2 & 51.53 & 3819.48 & 718.01 & 7.20 & 0.0062 \\
3 & 118.00 & 3815.96 & 644.83 & 147.62 & 0.3985 \\
4 & 224.48 & 3756.00 & 416.28 & 456.42 & 1.0892 \\
5 & 224.48 & 3756.00 & 133.26 & 584.44 & 1.3465 \\
6 & 258.72 & 3721.37 & 87.345 & 701.11 & 1.5746 \\
7 & 156.19 & 110.29 & 2.2011 & 558.61 & 1.6477 \\
8 & 70.31 & 103.83 & 2.6284 & 418.25 & 1.2917 \\
9 & 50.00 & 103.83 & 2.8125 & 390.12 & 1.2073 \\
\hline
\end{tabular}




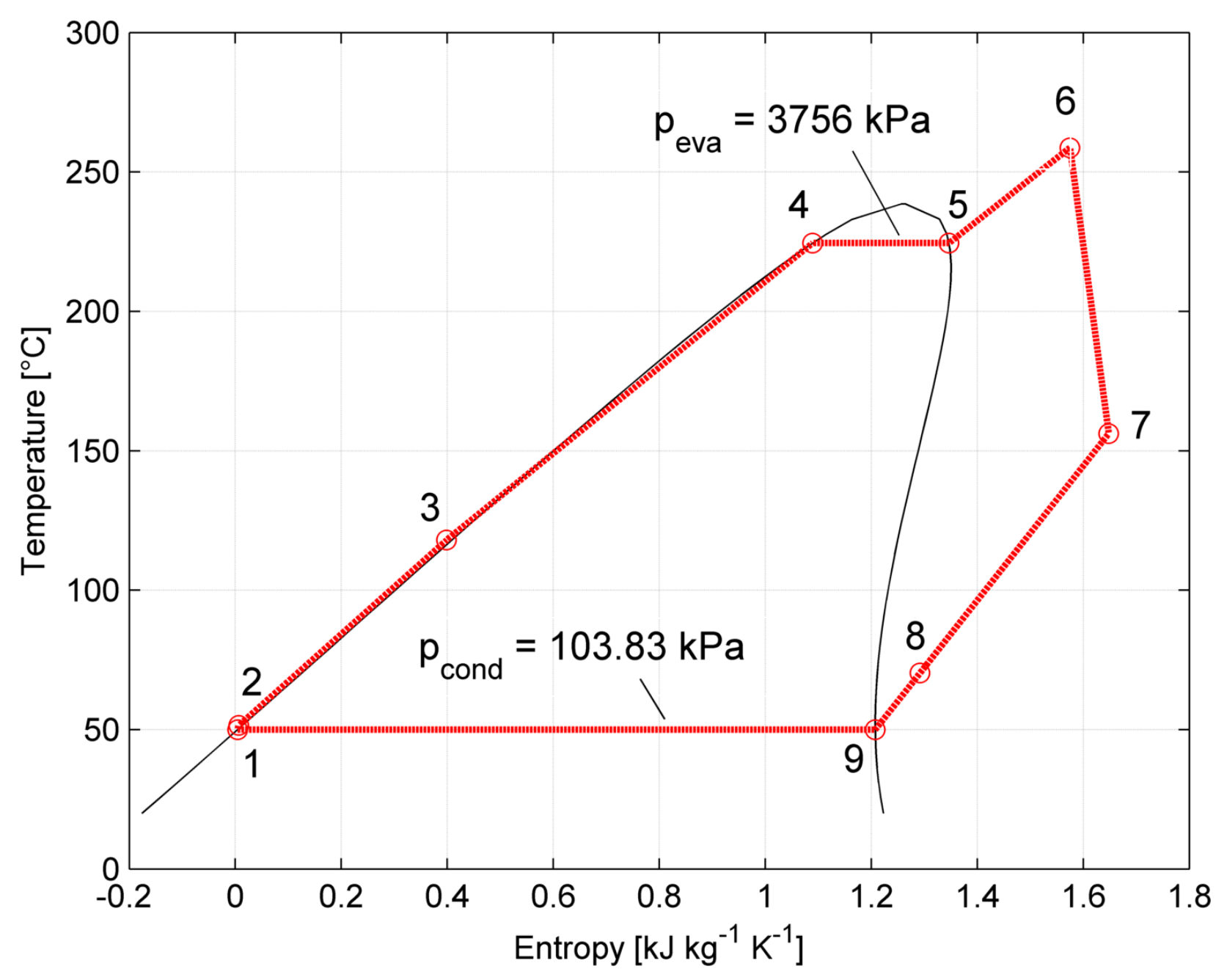

Figure B.12: Organic Rankine cycle $T$-s diagram. 
Table B.4: Design-point variables utilized to parametrize the dynamic model of the organic Rankine cycle system.

Component Parameters

\section{Once-through boiler}

Number of tube rows 63

Number of tubes in parallel $\quad 64$

Longitudinal and Transverse tube pitch $83 \mathrm{~mm}$

Tube inner diameter $\quad 38 \mathrm{~mm}$

Tube thickness $3 \mathrm{~mm}$

Tube length $\quad 2.44 \mathrm{~m}$

Number of fins $\quad 227 \mathrm{~m}^{-1}$

Fin height $15 \mathrm{~mm}$

Fin thickness $\quad 1 \mathrm{~mm}$

Tube wall density $\quad 7700 \mathrm{~kg} \cdot \mathrm{m}^{-3}$

Tube wall specific heat capacity $\quad 500 \mathrm{~J} \cdot \mathrm{kg}^{-1} \cdot \mathrm{K}^{-1}$

Fin thermal conductivity $\quad 40 \mathrm{~W} \cdot \mathrm{m}^{-1} \cdot \mathrm{K}^{-1}$

Recuperator

Volume (cold side) $\quad 1.99 \mathrm{~m}^{-3}$

Volume (hot side) $\quad 20.3 \mathrm{~m}^{-3}$

Weight (metal walls) $\quad 16.6$ ton

UA-value $\quad 202.3 \mathrm{~kW} \cdot \mathrm{K}^{-1}$

Turbine

Throat flow passage area $\quad 0.040 \mathrm{~m}^{2}$

Isentropic efficiency $\quad 81 \%$

Electric generator efficiency $\quad 98 \%$

\section{Pump}

Delivery pressure

$3852.5 \mathrm{kPa}$

Inlet pressure

$101.83 \mathrm{kPa}$

Isentropic efficiency

$72 \%$ 


\section{References}

2 [1] Hung, T.C., Shai, T.Y., Wang, S.K.. A review of Organic Rankine Cycles (ORCs) for the recovery of low-grade waste heat. ENERGY 1997;22(7):661-667.

[2] Andersen, W.C., Bruno, T.J.. Rapid screening of fluids for chemical stability in Organic Rankine Cycle applications. INDUSTRIAL and ENGINEERING CHEMISTRY RESEARCH 2005;44(15):5560-5566.

[3] Tchanche, B.F., Lambrinos, G., Frangoudakis, A., Papadakis, G.. Low-grade heat conversion into power using organic Rankine cycles - a review of various applications. Renewable and Sustainable Energy Reviews 2011;15(8):3963-3979.

[4] Orosz, M.S.. Small scale solar ORC system for distributed power in Lesotho. 29th ISES Biennial Solar World Congress 2009, ISES 2009 2009;2:1042-1048.

[5] Delgado-Torres, A.M., Garcia-Rodriguez, L.. Analysis and optimization of the low-temperature solar organic Rankine cycle (ORC). ENERGY CONVERSION AND MANAGEMENT 2010;51(12):2846-2856.

[6] Guo, T., Wang, H.X., Zhang, S.J.. Selection of working fluids for a novel low-temperature geothermally-powered ORC based cogeneration system. ENERGY CONVERSION AND MANAGEMENT 2011;52(6):2384-2391.

[7] Rayegan, R., Tao, Y.X.. A procedure to select working fluids for Solar Organic Rankine Cycles (orcs). RENEWABLE ENERGY 2011;36(2):659-670.

[8] Bocci, E., Villarini, M., Bove, L., Esposto, S., Gasperini, V.. Modeling small scale solar powered ORC unit for standalone application. Mathematical Problems in Engineering 2012;:124280.

[9] Wang, Z., He, S., Li, J., Song, G.. Modeling and testing a screw expander integrated into a trilateral flash cycle. MANUFACTURING SCIENCE AND TECHNOLOGY, PTS 1-8 2012;383-390(383-390):727-733.

[10] Amoresano, A., Meo, S., Langella, G.. Cycle efficiency optimization for ORC solar plants. International Review of Mechanical Engineering 2013;7(5):888-894.

[11] Ferrara, F., Luongo, A., Gimelli, A.. Small-scale concentrated solar power (CSP) plant: ORCs comparison for different organic fluids. Energy Procedia 2013;45:217-226.

[12] Ozcan, H., Dincer, I.. Thermodynamic analysis of an integrated SOFC, solar ORC and Absorption Chiller for Tri-generation applications. FUEL CELLS 2013;13(5):781-793.

[13] Marshall, R.. Ocean thermal energy conversion. Sunworld 1985;9(4):119-121, 128.

[14] Nihous, G.C.. A preliminary assessment of ocean thermal energy conversion resources. Journal of Energy Resources Technology 2007;129(1):10-17.

[15] Magesh, R.. OTEC technology- a world of clean energy and water. WCE 2010 - World Congress on Engineering $20102010 ; 2: 1618-1623$.

[16] Etemadi, A., Emdadi, A., AsefAfshar, O., Emami, Y.. Electricity generation by the ocean thermal energy. Energy Procedia 2011;12:936-943. 
[17] min Liu, W., Chen, F.Y., Wang, Y.Q., Zhang, J.G.. Progress of closed-cycle OTEC and study of a new cycle of OTEC. Advanced Materials Research 2011;354-355(1):275-278.

[18] Borsukiewicz-Gozdur, A., Nowak, W.. Maximising the working fluid flow as a way of increasing power output of geothermal power plant. APPLIED THERMAL ENGINEERING 2007;27(11-12):2074-2078.

[19] Bronicki, L.Y.. Organic Rankine Cycles in geothermal power plants 25 years of ormat experience. Transactions - Geothermal Resources Council 2007;31:499-502.

[20] Aneke, M., Agnew, B., Underwood, C.. Performance analysis of the chena binary geothermal power plant. APPLIED THERMAL ENGINEERING 2011;31(10):1825-1832.

[21] Guo, T., Wang, H.X., Zhang, S.J.. Fluids and parameters optimization for a novel cogeneration system driven by low-temperature geothermal sources. ENERGY 2011;36(5):2639-2649.

[22] Huan-lai, Z., Shang-ming, S., Chun-bo, H., Xiao-meng, F.. Study on the oilfield produced water geothermal resource utilization. Advanced Materials Research 2012;524-527(2):1284-1288.

[23] Li, T., Zhu, J., Zhang, W.. Cascade utilization of low temperature geothermal water in oilfield combined power generation, gathering heat tracing and oil recovery. APPLIED THERMAL ENGINEERING 2012;40:27-35.

[24] Li, T., Zhu, J., Zhang, W.. Comparative analysis of series and parallel geothermal systems combined power, heat and oil recovery in oilfield. APPLIED THERMAL ENGINEERING 2013;50(1):1132-1141.

[25] Thonhofer, P., Reisenhofer, E., Obernberger, I.. Description and evaluation of the new ORC process. Euroheat and Power/Fernwarme International 2002;31(10):18-25.

[26] Obernberger, I., Gaia, M.. Biomass-power-heat coupling based on the ORC process - state-of-the-art and possibilities for process optimization, biomasse - kraft-warme-kopplung auf basis des ORC-prozesses - stand der technik und molichkeiten der prozessoptimierung. VDI Berichte 2005;1(1891):131-148.

[27] Obernberger, I., Biedermann, F., Thonhofer, P., Gaia, M., Bini, R.. New small scale Organic Rankine Cycle ORC technology (200 kW electrical) for decentralized biomass power and heat coupling facility, neue kleinORC-technologie (200 kWel) fur dezentrale biomasse-kwk-anlagen. VDI Berichte 2008;1(2044):133-149.

[28] Rentizelas, A., Karellas, S., Kakaras, E., Tatsiopoulos, I.. Comparative techno-economic analysis of ORC and gasification for bioenergy applications. ENERGY CONVERSION AND MANAGEMENT 2009;50(3):674681.

[29] Qiu, G., Shao, Y., Li, J., Liu, H., Riffat, S.B.. Experimental investigation of a biomass-fired ORC-based micro-CHP for domestic applications. FUEL 2012;96(1):374-382.

[30] Chawla, V., Bundela, P.S.. Sustainable development through waste heat recovery. American Journal of Environmental Sciences 2010;6(1):83-89.

[31] Aneke, M., Agnew, B., Underwood, C.. Power generation from waste heat in a food processing application. Applied Thermal Engineering 2012;36:171.

[32] Tchanche, B.F., Quoilin, S., Declaye, S., Papadakis, G., Lemort, V.. Economic feasibility study of a small 
scale Organic Rankine Cycle system in waste heat recovery application. PROCEEDINGS OF THE ASME 10TH BIENNIAL CONFERENCE ON ENGINEERING SYSTEMS DESIGN AND ANALYSIS, 2010, VOL 1 $2010 ;: 249-256$.

[33] Qiu, G.. Selection of working fluids for micro-CHP systems with ORC. RENEWABLE ENERGY 2012;48:565570.

[34] Bao, J., Zhao, L.. A review of working fluid and expander selections for Organic Rankine Cycle. Renewable and Sustainable Energy Reviews 2013;24:325

[35] Tchanche, B.F., Pétrissans, M., Papadakis, G.. Heat resources and Organic Rankine Cycle machines. Renewable and Sustainable Energy Reviews 2014;39:1185.

[36] Pasetti, M., Invernizzi, C.M., Iora, P.. Thermal stability of working fluids for Organic Rankine Cycles: An improved survey method and experimental results for cyclopentane, isopentane and n-butane. Applied Thermal Engineering 2014;73(1):762 - 772.

[37] Badr, O., Probert, S.D., O’Callaghan, P.W.. Selecting a working fluid for a Rankine-cycle engine. Applied Energy 1985;21(1):1 - 42.

[38] Angelino, G.G., Invernizzi, C.C.. Cyclic methylsiloxanes as working fluids for space power cycles. ASME J Sol Energy Eng 1993;115(3):130-137.

[39] Schroeder, D.J., Leslie, N.. Organic Rankine Cycle working fluid considerations for waste heat to power applications. ASHRAE Transactions 2010;116(1).

[40] Tanzer, A.. Discussion of 'an overheat boiler tube failure'. Journal of Failure Analysis and Prevention 2006;6(2):31-32.

[41] French, D.N.. Metallurgical failures in fossil fired boilers. United States of America: Wiley; 1983. ISBN: 0471558397.

[42] Amendola, A.. Hot spot expectation in nuclear reactor core thermal design. Nuclear Science and Engineering 1972;49:106-108

[43] Zhang, X., Yu, M.Y., Shen, B.. Hot spot formation outside of the fusion-fuel core. Physics of Plasmas 2005;12(12):1-4.

[44] Gandini, A.. Hot point detection method. Annals of Nuclear Energy 2011;38:2843-2847.

[45] Francis, R.. Hot spot corrosion in condenser tube: its causes and prevention. British Corrosion Journal 1987;22:199-201.

[46] Prasher, R.S., Dirner, J., Chang, J.Y., Myers, A., Chau, D., Prstic, S., et al. Effect of localized hotspot on the thermal performance of two-phase microchannel heat exchanger. Proceedings of the ASME/Pacific Rim Technical Conference and Exhibition on Integration and Packaging of MEMS, NEMS, and Electronic Systems: Advances in Electronic Packaging 2005 2005;PART A:99-104.

[47] Benato, A., Stoppato, A., Bracco, S.. Combined cycle power plants: A comparison between two differ- 
ent dynamic models to evaluate transient behaviour and residual life. Energy Conversion and Management 2014;87:1269-1280.

[48] Pierobon, L., Nguyen, T.V., Larsen, U., Haglind, F., Elmegaard, B.. Multi-objective optimization of organic Rankine cycles for waste heat recovery: Application in an offshore platform. Energy 2013;58(0):538-549.

[49] Pierobon, L., Benato, A., Scolari, E., Haglind, F., Stoppato, A.. Waste heat recovery technologies for offshore platforms. Applied Energy 2014;136(0):228 - 241.

[50] Sector, S.A.E.. SGT-500 Industrial Gas Turbine. 2011. Available on: http://www.energy.siemens.com.

[51] Fast work for the benson once-through hrsg. Modern Power Systems 2004;24(2):23.

[52] Del Turco, P., Asti, A., Del Greco, A., Bacci, A., Landi, G., Seghi, G.. The ORegen waste heat recovery cycle: Reducing the $\mathrm{CO}_{2}$ footprint by means of overall cycle efficiency improvement. In: Proceedings of ASME Turbo Expo 2011. Vancouver, Canada; 2011, p. 547-556.

[53] Casella, F., Leva, A.. Modelling of thermo-hydraulic power generation processes using Modelica. Mathematical and Computer Modeling of Dynamical Systems 2006;12(1):19-33.

[54] Casella, F., Mathijssen, T., Colonna, P., Van Buijtenen, J.. Dynamic modeling of ORC power systems. Journal of Engineering for Gas Turbines and Power 2012;135:1-12.

[55] Kurzke, J.. Component map collection 2, Compressor and turbine maps for gas turbine performance computer programs. Germany; 2004. Available on: www.gasturb.de.

[56] Carchedi, F., Wood, G.R.. Design and development of a 12:1 pressure ratio compressor for the Ruston 6-MW gas turbine. Journal for Engineering for Power 1982;104:823 - 831.

[57] Kurzke, J.. How to create a performance model of a gas turbine from a limited amount of information. In: Proceedings of ASME Turbo Expo 2005. Reno-Tahoe, United States of America; 2005, p. 145-153.

[58] Stodola, A.. Dampf- und Gasturbinen: Mit einem Anhang über die Aussichten der Wärmekraftmaschinen. Berlin, Germany: Springer Berlin; 1922. ISBN: 7352997563.

[59] Schobeiri, M.. Turbomachinery flow physics and dynamic performance. Berlin, Germany: Springer Berlin; 2005. ISBN: 9783540223689.

[60] Camporeale, S.M., Dumas, A., Fortunato, B.. Dynamic modelling of recuperative gas turbine. In: Proceedings of the Institution of Mechanical Engineers, Part A: Journal of Power and Energy; vol. 3. Professional Engineering Publishing; 2000, p. 231-225.

[61] Haglind, F., Elmegaard, B.. Methodologies for predicting the part-load performance of aero-derivative gas turbines. Energy 2009;34(10):1484-1492.

[62] Pierobon, L., Iyengar, K., Breuhaus, P., Kandepu, R., Hana, M., Haglind, F.. Dynamic performance of power generation systems for off-shore oil and gas platforms. In: Proceedings of ASME Turbo Expo 2014. 2014,.

[63] Incropera, F.P., Lavine, A.S., DeWitt, D.P.. Fundamentals of heat and mass transfer. John Wiley and Sons; 2011. ISBN: 9780471457282. 
[64] Bell, I.H., Wronski, J., Quoilin, S., Lemort, V.. Pure and pseudo-pure fluid thermophysical property evaluation and the open-source thermophysical property library CoolProp. Industrial \& Engineering Chemistry Research 2014;53(6):2498-2508.

4 [65] Ginosar, D.M., Petkovic, L.M., Guillen, D.P.. Thermal stability of cyclopentane as an organic Rankine cycle working fluid. Energy \& Fuels 2011;25(9):4138-4144.

6 [66] Pierobon, L., Casati, E., Casella, F., Haglind, F., Colonna, P.. Design methodology for flexible energy conversion systems accounting for dynamic performance. Energy 2014;68:667-679.

[67] Dumont, M.N., Heyen, G.. Mathematical modelling and design of an advanced once-through heat recovery steam generator. Computers \& Chemical Engineering 2004;28(5):651-660.

[68] Modelon AB, . Thermal power library. 2014. Available on: www.3ds.com.

[69] Eiden, J., Enger, O., Peci, N., Rutkowski, S., Vahlenkamp, T., Wischhusen, S.. Fluid.dissipation library. 2013. URL: https://build.openmodelica.org/Documentation/Modelica.Fluid.Dissipation.html.

[70] Gnielinski, V.. New equation for heat and mass transfer in turbulent pipe and channel flow. International Chemical Engineering 1976;16:359-368.

[71] Petukhov, B.S.. Heat transfer and friction in turbulent pipe flow with variable physical properties. Advances in heat transfer 1970;6(503):i565.

[72] Shah, M.M.. Chart correlation for saturated boiling heat transfer: equations and further study. ASHRAE Transaction 1982;88(1):185-196.

[73] Verein Deutscher Ingenieure, . VDI-Wärmeatlas: Berechnungsblätter für den Wärmeübergang. Berlin, Germany: Springer-Verlag; 1953. ISBN: 9783540412014. 